\title{
The influence of spending time outside on experience of nature and environmental attitudes
}

Agathe COLLÉONY*a, Rachel WHITE ${ }^{\mathrm{b}}$ and Assaf SHWARTZ ${ }^{\mathrm{a}}$

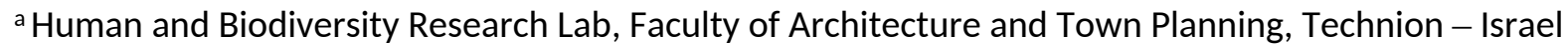
Institute of Technology, Haifa, 32000 Israel

${ }^{\mathrm{b}}$ School of Pharmacy and Biomolecular Sciences, University of Brighton, Brighton, UK

* corresponding author: agathe.colleony@gmail.com

\section{Acknowledgements}

We wish to thank D. Bashan for her help in translating the questionnaires in Hebrew and recruiting the participating dog shelters in Israel. We also thank R. Cohen for her help keeping in touch with participating dog shelters in Israel. H. Segre assisted by coding Hebrew responses for environmental knowledge questions. Finally, we are grateful to all managers of the dog shelters for their participation in the project. This research was funded by the Israel Science Foundation (Grant No. 1456/16) and A.C. was also partly supported by the Technion Fellowship for distinguished postdoctoral fellows. 


\section{Abstract}

2 Urbanization threatens biodiversity and people's opportunities to interact with nature. This progressive disconnection from the natural world is profoundly concerning as it affects human health, wellbeing, attitudes and behaviors towards nature. Increasing the quantity of experiences of nature (EoN) can enhance health and wellbeing benefits, but it remains unclear whether it can also

6 affect environmental attitudes across different countries. Here, we conducted a cross-cultural survey

7 among 741 people from France, Israel and the UK, who either own a dog (and thus prone to go

8 outdoors to walk their dog), a cat, or no pet. This setting was used as a quasi-experiment to explore

9 the relationships between EoN, nature relatedness, environmental knowledge and attitudes. Our results confirmed that dog-owners have a higher quantity of EoN. However, we found that although dog-ownership was associated with people's relatedness to nature, the increased quantity of EoN did not correlate with environmental knowledge or attitudes. Thus, increasing the quantity of EoN may not be sufficient for mitigating the effects of the extinction of experience and consequently a more profound understanding of the quality of EoN and the means to enhance it are needed. This knowledge is crucial to help landscape planners provide accessible and suitably designed green spaces that can foster meaningful interactions with nature, for instance through specific gardening practices or creative design. cultural 


\section{Introduction}

Species extinctions are continuing at alarming rates (Rands et al., 2010), and human activity is largely driving this crisis (Cardinale et al., 2012). Solutions therefore lie in changing people's attitudes and behaviors towards the natural environment (Keniger, Gaston, Irvine, \& Fuller, 2013), but the same processes that threaten biodiversity (e.g. urbanization; Seto, Güneralp, \& Hutyra, 2012) also increasingly separate people from the natural world (Soga \& Gaston, 2016). This is profoundly concerning since mounting empirical evidence demonstrates that experiences of nature (EoN) can provide a wide range of physiological and psychological benefits to people (Shanahan et al., 2016). The increasing alienation from nature, so-called 'extinction of experience', is likely to progressively diminish the importance people assign to the natural world, creating a cycle of impoverishment of EoN with dramatic consequences in terms of conservation (Soga \& Gaston, 2016). Thus, mitigating the extinction of experience is rising as a key contemporary issue, if we are to advance the conservation agenda (Miller, 2005). In search of a solution, previous studies advocate for increasing the quantity of EoN by providing more opportunities for people to experience nature, especially in urban environments, i.e. providing more greenspaces or natural features close to where people live and work (e.g., Miller, 2006; Soga, Gaston, Koyanagi, Kurisu, \& Hanaki, 2016; Soga et al., 2015).

EoN are a central foundation for fostering an individual's sense of belonging to the natural world (e.g. nature relatedness; Nisbet, Zelenski, \& Murphy, 2009) and knowledge about it (Bögeholz, 2006), which in turn can lead to the development of pro-environmental attitudes (Clayton \& Myers, 2009). These attitudes in turn can translate into behavioral intentions and behaviors, although this does not always hold true as other psycho-social variables mediate this relationship (e.g. personal moral norms; Bamberg \& Möser, 2007). We propose a theoretical model linking EoN to pro-environmental behaviors and inspired from Clayton and Myers (2009; Fig. 1a). To date, most studies that explore EoN have focused on the impact of EoN during childhood on environmental attitudes at adulthood. These studies demonstrate that childhood exposure to nature is a strong predictor of the type of natural places visited and environmental beliefs and commitment at adulthood (Colléony, Prévot, 
Saint Jalme, \& Clayton, 2017; Wells \& Lekies, 2006). However, nature relatedness and environmental knowledge develop over an individual's life and not entirely during childhood. Research exploring the links between current EoN and environmental attitudes among adults are still scarce and this hinders our ability to plan green spaces that can reconnect people with conservation issues.

Also, a variety of different measures of human-nature relationships have been used interchangeably, and although some research have demonstrated that these measures are highly correlated and concur in capturing similar concepts (e.g. nature relatedness; Tam, 2013), very few comparative studies or meta-analyses have been conducted. We are only aware of one recent meta-analysis used to assess relationship between mindfulness and connectedness to nature (Schutte \& Malouff, 2018). Despite cultural differences in landscape preferences or benefits people retain from green spaces, cross-cultural surveys are still lacking. For instance, a study conducted in the Netherlands found that, when shown different sets of nature images, local Dutch people were strong supporters of images showing landscapes with no human influence, while recent immigrants from Turkey and Morocco generally supported presented images depicting intensively managed landscapes (Buijs, Elands, \& Langers, 2009). A recent multi-continental study also demonstrated that the relationship between green spaces and population health is positive in wealthy countries but negative in poorer ones, and thus might be context dependent (Amano, Butt, \& Peh, 2018). The extent and type of EoN is thus likely to vary across countries, especially with differing cultures and could, in turn, differently affect people's sense of relatedness to nature, environmental knowledge and attitudes. The abovementioned shortcomings hinder the ability to understand to what extent promoting broad policies that aim to increase EoN can also promote stewardship for the natural environment, beside their apparent benefits to people's health and wellbeing (Pett, Shwartz, Irvine, Dallimer, \& Davies, 2016).

One approach that can help to bridge these knowledge gaps is to identify certain conditions that influence the time people spend outdoors. Such settings can be used to explore the influence of EoN 
on nature relatedness and environmental knowledge and their effect on environmental attitudes. Pet ownership can represent such a quasi-experimental setting. Pets are present in many households worldwide and affective connection to animals has been shown to be positively related to selfreported pro-environmental behaviors (Grajal et al., 2016). Most importantly, some pets (e.g. dogs) actively encourage going outdoors (e.g., Toohey \& Rock, 2011), and are thus expected to increase, at least quantitatively, their owners' EoN. Dog walking is a frequent greenspace activity (White et al., 2016), especially within close proximity to the owner's home (Elliott, White, Taylor, \& Herbert, 2015).

\section{$<$ Place figure 1 here $>$}

Here, we conducted a cross-cultural survey involving dog-, cat- and non-pet owners to explore the impact of increased quantity of EoN on environmental attitudes. Specifically, we aimed to verify our assumption that dog owners have a greater 'quantity' of EoN and explore whether this is in turn positively correlated with nature relatedness, environmental knowledge and attitudes (Fig. 1b). We used a mixed-method approach, with an online survey across three countries (i.e. France, Israel and the UK), that measured respondents' quantitative EoN (i.e. the frequency of visits to outdoor spaces), nature relatedness, environmental knowledge and attitudes, and an experimental study in dog shelters to measure respondents' quantitative EoN and nature relatedness both before and after adoption of a dog. The cat owners' group served as a control group for pet owners, as both cats and dogs are sources of emotional attachment for their owners, but unlike dogs, cats are not expected to have a strong impact on their owners' quantity of EoN.

\section{Material and methods}

\subsection{Study design}

\subsubsection{Online questionnaire}

The survey was administered to participants living in three countries: two in Europe (France and the UK) and one in the Middle East (Israel). Studies investigating the topic of the extinction of experience have mostly been conducted in Anglo-Saxon countries, and we wished to bridge this gap by including 
other languages. We hypothesized that responses would be relatively similar in France and the UK, for cultural and geographical reasons. Alternatively, we expected different answers from a middleEastern country with rapidly increasing urban population. The questionnaire was translated by native speakers from English to French and Hebrew as appropriate. In each country, we targeted dog-, catand non-pet owners. The questionnaire was piloted in the three countries in June 2017 using a focus group approach, whereby six people per country were asked to check for understanding and provide feedback on the questions. We then distributed the online survey in July 2017 across the three countries using panels of respondents of a market-based company (Qualtrics), which ensured to survey a balanced distribution of gender, pet owners, age and education levels, within each country. In return for participation, Qualtrics offered participants to receive incentives. We sampled 741 people in total, with 258 French, 174 Israeli and 309 UK respondents, from all age categories and education levels, but with a slight predominance of urban dwellers than rural inhabitants (more than $60 \%$ of respondents within each country; see Table A1).

\subsubsection{Dog shelter questionnaire}

The online survey only allowed us to determine whether dog owners have a greater quantity of EoN and perhaps greater nature relatedness, without providing more information on the direction of the relationship. In an attempt to explore the causal link between owning a dog and both EoN and nature relatedness, we surveyed people adopting a dog twice: at the moment of adoption and two months after adoption. We recruited seven dog shelters in total, from the three countries and asked the managers to distribute a reduced version of the online questionnaire to adoptees and also asked participants to provide their email address, so that we could contact them for the post survey. Approximately two months after adoption, we contacted the participants and invited them to participate in a similar online survey. Dog shelters distributed the questionnaires from end of June to mid-September 2017. Post-surveys were sent and completed online in November 2017.

\subsection{Questionnaire design}


The questionnaire was designed to capture whether respondents own a pet, as well as their EoN, nature relatedness, environmental knowledge, environmental attitudes, awareness of the impact of dogs on biodiversity and socio-demographic variables.

Pet ownership was measured by asking each respondent whether they owned only a dog(s), only a cat(s), another pet(s) or no pet(s). Respondents owning 'another pet(s)' were screened out during the survey. Respondents who reported no pet ownership were then asked whether they previously owned a dog (including during childhood).

To assess EoN, respondents were first asked to report the frequency of visits during the past month to seven different types of outdoor places (see Table A2) on a 5-point scale (1: Did not visit last month, 2: Less than once a week, 3: Once a week, 4: More than once a week, 5: Everyday), adapted from Schipperijn et al. (2010). For this question, we did not specify whether the visits were with or without the pet (if relevant), and therefore referred to visits to outdoor places in general. Pet owners were then asked the same question but regarding visits specifically with their pet. Two variables were created to measure EoN: the frequency of visits was calculated by averaging the seven scores of items that measured frequency of visit to different outdoor places overall (Cronbach's alphas; 0.70 in France and the UK, and 0.60 in Israel). We also calculated the number of different places participants visited during the past month overall (i.e. excluding places with a frequency score of 1 ), to assess the diversity of outdoor places people visited (Number of places). Similarly, we measured EoN specifically with the pet, with frequency of visits with the pet and number of places visited with the pet.

Nature relatedness was measured using the 6-item Nature Relatedness scale (NR) (Nisbet \& Zelenski, 2013). Each respondent was asked to rate their level of agreement to each statement on a 5-point scale, from 1-Strongly disagree to 5-Strongly agree. Based on confirmatory factor analyses and satisfactory reliability for the NR scale across the three countries (Cronbach's alphas; 0.86 in France, 0.83 in Israel and 0.87 in the UK), we averaged the scores from the six items of NR to derive a single measure of Nature Relatedness per individual. 
To measure environmental knowledge, we analyzed participants' ability to identify species (following Dallimer et al., 2012; White, Eberstein, \& Scott, 2018). Although environmental knowledge is multifaceted, species identification has been acknowledged as a fundamental component (Pilgrim, Cullen, Smith, \& Pretty, 2008). The progressive disconnection of people from nature, particularly in Western countries, is resulting in a loss of environmental knowledge - including the ability to identify even the most common species (Miller, 2005; Pilgrim et al., 2008). Since the species is the fundamental unit of biodiversity, it has been argued that being able to identify at least some animal and plant species is crucial in the biodiversity understanding process (Lindemann-Matthies, 2005; Randler, 2008). Following Dallimer et al. (2012), respondents were shown 12 images of common bird, butterfly and plant species, and first asked to tick the ones they recognized. We selected species that were common in most or all of the three countries, and when it was not possible in one of the countries, we adapted with another morphologically similar species that is more common in this country (e.g. for plants: Papaver rhoeas was shown in France and the UK, Papaver unbonatum in Israel) (see Table A2). Then, respondents were asked to name the ones they knew (i.e., common name).

Environmental knowledge was calculated based on the number of species participants managed to identify correctly. We first attributed a score of subjective knowledge for each participant based on the number of species they think they know (i.e. number of species ticked). To make sure each participant really ticked the species they knew, we then analyzed identifications of species, and determined each as either correct, partially correct or incorrect. To score correct, the full common name had to be given; e.g. great tit. If only the common genus or family name was correct then it scored partly correct (e.g. tit instead of great tit), otherwise we classified the answer as incorrect. Spelling was not penalized as long as the common name could be determined. We summed the twelve scores per individual to build a score of objective knowledge. Although subjective knowledge was correlated to objective knowledge (Pearson's correlation: $\mathrm{df}=437, p<0.001 ; r=0.7$ ), participants' 
knowledge was actually lower than what they indicated. We retained the score of objective knowledge as a score of Environmental knowledge for data analysis.

Environmental attitudes were assessed through a 5-item reduced version (Stern, Dietz, Abel, Guagnano, \& Kalof, 1999) of the New Ecological Paradigm (NEP; Dunlap, Van Liere, Mertig, \& Jones, 2000). Respondents were asked to rate their level of agreement to each statement on a 5-point scale, from 1-Strongly disagree to 5-Strongly agree. Based on confirmatory factor analyses and satisfactory reliability for the NEP scale across the three countries (Cronbach's alphas; 0.6 in France and Israel, and 0.7 in the UK), we averaged the scores from the five items of NEP to derive a single measure of Environmental attitudes per individual. We also measured whether respondents were aware of the impact of pets (i.e. dogs and cats) on biodiversity, by asking them whether they think dogs and cats endanger biodiversity on 5-point scales, from 1-Strongly disagree to 5-Strongly agree.

Finally, we collected socio-demographic information by asking respondents to indicate the country they currently live in, their gender, age group, and their highest level of education (Table A1). Because exposure to nature both during childhood and as an adult is an important factor of EoN and nature relatedness, we also asked respondents to report both the level of urbanization of where they currently live (current urbanization; Table A1) and where they lived during childhood (childhood urbanization) using a 4-point scale (see Table A2) following Shwartz et al. (2013).

\subsection{Data analyses}

To verify the assumption that dog owners go out more often and in more diverse outdoor places than cat- and non-pet owners, we built two linear models based on the online survey data.

Frequency of visits (model 1 ) and number of places (model 2) were used as dependent variables, and country, pet ownership, current urbanization, childhood urbanization, and the three sociodemographic variables, as independent variables. Because the relationship between NR and EoN can be bi-directional, we included NR as an independent variable in these two models. To verify our assumption that dogs are more likely to encourage owners to spend time outside, in comparison to 
cats, we compared the number of dog/cat owners who take their dog/cat outside using a chi-squared test. For dog owners, we also explored the correlation (Pearson) between the overall EoN (frequency of visits and number of places visited) and the experience of nature variables related to visits specifically with the dog.

We further explored whether a potential increased quantity of EoN, through dog ownership, was significantly related to increases in NR (model 3), environmental knowledge (model 4) and attitude (model 5), and awareness of the impact of dogs and cats on biodiversity (models 6 and 7 , respectively) through five distinct linear models. In these models, NR, environmental knowledge and attitudes, and awareness of the impact of dogs and cats on biodiversity were used as dependent variables, respectively. We included the same independent variables as in models 1 and 2. Based on our theoretical model (Fig. 1a), we added NR as an independent variable in models 4 to 7; we also added environmental knowledge as an independent variable in models 5 to 7 . We included all possible interaction effects except those with the socio-demographic variables. All analyses were conducted using R 3.3.3 (R Core Team, 2013). We checked the normality assumption by plotting the residuals and checked for multicollinearity using variance inflation factors. Post-hoc comparisons were performed for the effects of pet and country using Tukey HSD tests. We conducted stepwise model selection based on the Akaike Information Criterion; stepwise deletion was carried out on the basis of non-significant $p$-values, with largest $p$-values and interactions removed first.

Finally, to test our hypothesis that potential increases in EoN and NR result from owning a dog (and not the other way around), we ran ANOVAs and post-hoc tests to compare the different groups from the two surveys: (a) online - dog owner, (b) online - cat owner, (c) online - non-pet owner, and (d) dog shelter - before adoption. Demonstrating that group (d) has significantly lowers scores than group (a), and no significant difference with group (c) would give support to our hypothesis. We also compared frequency of visits and NR for dog shelter participants, before and after adoption, but did not run any statistical tests, given the low sample size (see results). 


\subsection{Ethics statement}

Permission for this survey was granted by the Technion Social and Behavioral Sciences Institutional Review Board (approval number: 2017-45), and the research was performed in accordance with relevant guidelines and regulations. All participants were provided with a brief description of the study and gave informed consent for study participation. All responses were anonymous. English versions of the surveys can be found in Appendix B.

\section{Results}

\subsection{Dog owners go out more often and in more diverse places}

Our results indicate that dog owners visit outdoor places more frequently and more types of outdoor places compared to cat- and non-pet owners, and that cat owners did not differ from non-pet owners (Fig. 2). Among pet owners, we found that most cat owners do not take their cat out, while most dog owners take their dog out $\left(\chi^{2}=258.74, p<0.001\right)$, confirming that owning dogs motivates people to go out, while having cats does not. For dog owners, we found that the overall EoN variables were correlated with frequency of visits and the number of places specifically visited with dogs $\left(r_{\text {Freq }}=0.68\right.$ and $r_{\text {Nplaces }}=0.72$, respectively). NR was significantly related to the EoN variables, suggesting that respondents who had greater scores of NR reported visiting more often and more diverse outdoor places (Table 1). French and UK respondents reported significantly higher frequencies of visits and number of outdoor places visits than Israeli respondents (Fig. 3). The relationship between NR and frequency of visits was stronger for French and UK respondents than for Israeli ones (Table 1; Figure A1).

<Place figure 2 here $>$

<Place table 1 here> 


\subsection{Impact of increased quantity of EoN on NR, environmental knowledge and attitudes}

Based on the online survey, dog owners felt more related to nature than non-pet owners $(N=741$; mean $_{N R}(S D)=3.50(0.05) ;$ mean $_{N R}(S D)=3.24(0.05)$, respectively), but NR did not differ from cat owners $\left(\operatorname{mean}_{\mathrm{NR}}(\mathrm{SD})=3.50(0.06)\right.$; Table 2). French respondents reported higher scores of NR than Israeli ones, with scores in between for UK respondents (Fig. 3). Environmental knowledge did not significantly differ between dog-, cat- and non-pet owners, but was significantly associated with NR. UK respondents showed stronger environmental knowledge than French respondents, who also scored significantly higher than Israeli respondents.

Environmental attitudes were positively associated with environmental knowledge and NR (Table 2).

Environmental knowledge was also positively related to awareness of the impact of dogs/cats on biodiversity for UK and Israeli respondents, but these relationships were negative for French respondents (Table 2; Figure A1). We did not find any significant difference for environmental attitudes and awareness of the impact of dogs on biodiversity between dog-, cat- and non-pet owners. Cat owners showed lower awareness of the impact of cats on biodiversity than dog owners. French respondents reported stronger environmental attitudes than UK and Israeli respondents, but UK respondents were more aware of the impact of dogs/cats on biodiversity than French and Israeli respondents (Fig. 3).

\section{<Place table 2 here>}

\subsection{Dogs positively affect EoN and NR}

We recruited one dog shelter in France, four in Israel and two in the UK, and collected 15, 25, and 10 questionnaires, respectively ( $\left.\mathrm{N}_{\text {tot }}=50\right)$, at adoption ('before'). We then collected only 12 responses for the post-survey ('after'). Comparing the results of the dog shelter and the online survey revealed that before adoption, respondents had significantly lower frequency of visits and number of places visited than dog owners from the online survey (hence, giving support to our hypothesis), but also 
compared to other respondents from the online survey ( $N=791$; ANOVAs: $F=12.18, p<0.001$ and $F=3.92, p=0.008$, respectively). We also found that dog shelter respondents had significantly higher NR scores than dog-, cat- and non-pet owners from the online survey ( $N=791$; ANOVA: $F=25.07$, $p<0.001$ ). Finally, although the sample size is very low, we found that both frequency of visits and NR increased after adoption of a dog at a shelter $\left(\mathrm{N}=12\right.$; mean $_{\text {Freq_before }}(\mathrm{SD})=2.24(0.78)$ and mean $_{\text {Freq_after }}$ $(S D)=2.41(0.64) ;$ mean $_{\text {NR_before }}(S D)=3.87(0.77)$, mean $\left._{\text {NR_after }}(S D)=3.92(0.69)\right)$.

\section{Discussion}

The extinction of experience leads to a cycle of impoverishment, in which people are increasingly alienated from EoN and as a result their affinity to the natural world and its protection is weakened (Miller, 2005). This cycle may hinder the ability to achieve the required changes in environmental attitudes and behaviors, and therefore averting the extinction of experience should be regarded as a major contemporary conservation objective (Soga \& Gaston, 2016). Providing more green spaces and natural features in cities and encouraging people to spend time outside are sometimes suggested as means to mitigate this extinction of experience (e.g., Soga \& Gaston, 2016; Soga et al., 2015). Our results demonstrate that this relationship is not as straightforward as commonly argued. On the one hand, we verified the theoretical model suggested by Clayton and Myers (2009; Fig. 1a), demonstrating that spending more time outdoors in more diverse places can be related to connection to nature. The latter was found to be positively related with both environmental knowledge and attitudes. However, our results challenge the concept that simply spending more time outside may be sufficient to affect environmental attitudes (Soga \& Gaston, 2016). Finally, although our cross-cultural study design verified the generality of the theoretical model we explored, we did find significant cultural differences in all variables measured. This suggests that people may connect differently to nature across countries and therefore one-size-fits-all solutions might not be well-suited for addressing the extinction of experience.

\subsection{One size may not fit all}


Only a few studies have explored cultural differences in people's EoN and to our knowledge, none

298 have compared sense of belonging to and knowledge about the natural environment. Franzen and

299 Vogl (2013) demonstrated that Israeli respondents had lower environmental concern than French

300 and British citizens. In accordance, we found that Israeli respondents systematically scored the lowest on all components, including environmental knowledge and attitudes. Franzen and Vogl (2013) suggested that differences in wealth can explain the variation in environmental concern. They argue that wealthy individuals or countries have fewer economic concerns and are therefore liberated to turn to other issues, e.g. regarding the environment. The three countries we studied are all relatively wealthy countries, but unlike France and the UK, in Israel the geopolitical situation preserves existential concerns that may marginalize environmental issues. These findings highlight a concern regarding the ability to promote policies and achieve the behavioral change needed to protect biodiversity in Israel, which is often considered as an ecological hotspot (Brooks et al., 2002) and currently facing high demographic growth and urban expansion (CBS, 2017). Cultural differences in green space use could explain the low EoN of Israeli respondents, as it was demonstrated for Turkey compared to other Western countries in a previous study (Özgüner, 2011).

Interestingly, French respondents scored higher for nature relatedness, while UK respondents scored higher on the knowledge aspect. These results are challenging to interpret, due to the lack of crosscultural research on the topic. A recent multi-continental study demonstrated that the relationship between health benefits and green spaces is not always positive, and that these benefits are contextdependent and vary across countries (Amano et al., 2018). It is therefore crucial to expand existing research beyond more developed countries and document cross-cultural differences. We should recall that one size may not fit all when promoting policies aiming to enhance nature interactions.

319 Governmental agencies and NGOs worldwide should be aware of these differences and use them 320 when developing conservation outreach activities: for instance, using more knowledge-related approaches in England, while focusing more on one's sense of relatedness to nature in France. A previous study in France showed that attractiveness for an animal species influenced people's choice 
of which species to conserve more than its conservation status (Colléony, Clayton, Couvet, Saint Jalme, \& Prévot, 2017). On the other hand, there is also a need to develop and tailor policies and activities that can strengthen nature relatedness and/or environmental knowledge, such as citizen science (Schuttler, Sorensen, Jordan, Cooper, \& Shwartz, 2018).

\subsection{The conservation role of dogs}

The assumption that owning dogs brings people outdoors, more often and in more diverse places, was corroborated across cultures, even after accounting for other variables that have been found to influence EoN in previous studies (i.e. childhood and current urbanization, age, education; Shwartz et al., 2013). Owning pets in general and dogs in particular was also highly correlated to people's NR (Fig. 1b). Interestingly, NR of people who were going to or just adopted a dog at a shelter was significantly higher than all other groups of participants. This result is in line with Nisbet et al. (2009) who found that people with high NR scores demonstrated an affiliation with animals, and may suggest that owning a dog, and to a higher extent the moment of adopting one, is an activity that enhances sense of connection to nature. The strong relation between dog-ownership, NR and EoN, highlights the potential value of owning a dog for conservation.

These results are interesting in the light of recent studies that flag some negative impacts of dogs on biodiversity (Banks \& Bryant, 2007; Doherty et al., 2017), although it remains relatively undocumented whether they also have such a negative impact in more poorly-biodiverse areas like urban green spaces. Beyond the detrimental ecological impacts of pets, we show that they can also have some indirect conservation benefits, through connection to the natural world and spending more time outside. It is therefore important to carefully consider the conservation benefits of pets in general and dogs in particular, when advocating for policies such as restrictions/bans on dog walking. Promoting policies and programs that increase awareness of the impacts of pets on wildlife seems a more appropriate approach, given the high affinity to nature and the low overall awareness for the ecological impacts of dogs and cats revealed here and elsewhere (McDonald, Maclean, Evans, \& 
Hodgson, 2015). This could help dog owners to be more sensitive to biodiversity conservation, e.g. by keeping their dog on leash in more sensitive habitats.

\subsection{Moving from quantity to quality of EoN}

Visiting outdoor places more frequently (through dog ownership) did not translate directly into greater environmental knowledge or attitudes, as we expected (Fig. 1). Dog owners have the responsibility to take their dogs outdoors, but this activity might not result in a profound interaction with nature while walking the dog.

The main consequences of the extinction of experience are twofold: first on human health and wellbeing, and second, on sense of relatedness to nature and willingness to protect it. It has been shown that even indirect EoN (e.g. viewing nature images) can have positive effects on health and wellbeing (Keniger et al., 2013) and particularly that dog ownership is related to physical activity and health (Christian et al., 2013). In England, dog walking is the most frequent green space activity (White et al., 2016), and most dog walking occurs within 2 miles of home (Elliott et al., 2015). A recent study demonstrated that in this country, neighborhood greenspace is related to physical activity, but only for dog owners (White, Elliott, Wheeler, \& Fleming, 2018). A longitudinal study provided support that dogs may help their owners remain active across seasons (Lail, McCormack, \& Rock, 2011). This suggests that dog walking can contribute to mitigating the first consequence of the extinction of experience. Public policies forbidding dogs in public parks in large cities may therefore not be an adequate solution. For instance, in Paris, most parks are currently forbidden to dogs (413 out of the 490 in total; www.paris.fr/jardins, accessed December 11, 2018). Dog owners are important users of local green and dog walking can help promote public health, through physical activity (White et al., 2018) and social contacts (Wood, Giles-Corti, \& Bulsara, 2005; Wood et al., 2015). Therefore, more dog-friendly policies regarding the use of green spaces could help promote public health. Accordingly, the city of Paris is now in the process of allowing dogs on a leash in all urban parks (Gairaud, 2018). 
Regarding the second main consequence of the extinction of experience, it appears that dog walking constitutes an incidental EoN (e.g. crossing a park on the way to work) rather than an intentional EoN (e.g. going to a park to watch birds) (Keniger et al., 2013). Perhaps this type of experience is not sufficient to strengthen knowledge and care for nature. People who walk their dogs may get distracted by many things (e.g. mobile phones and social interactions) that hinder them from having meaningful EoN that is needed to mitigate the extinction of experience. In accordance, Lin et al. (2014) previously showed that NR is a much stronger driver for EoN than opportunity, i.e. access to green places/nature. Another study demonstrated that experiencing more complex nature during childhood is more likely to trigger environmental behaviors at adulthood than experiencing a more 'domesticated nature' (Wells \& Lekies, 2006). Hence, not all outdoor experiences can have the same influence on environmental attitudes, and we need to scale-up from simplistic approaches regarding the EoN.

The importance of considering the different dimensions of EoN, when exploring conservation-related outcomes was recently highlighted (Clayton et al., 2017). For instance, EoN may largely vary in quality, depending on an individual's behaviors, emotions, or intensity of nature they experience (Clayton et al., 2017; Shanahan, Fuller, Bush, Lin, \& Gaston, 2015). Despite the fact that increasing the quantity of EoN is often sufficient to affect health and wellbeing (Shanahan et al., 2016), our results suggest that simply providing more green infrastructures where people live and enhancing frequency and time spent in green and open environments may not be adequate to contribute to the mitigation of the extinction of experience and its conservation consequences. Instead, we need to understand how to enhance meaningful positive EoN by providing accessible and suitably designed green space that can foster meaningful experiences. To do so, research effort should now focus on both quantity (e.g. frequency and duration, as done so far) and quality of EoN (e.g. looking at people's behaviors towards the natural world, like observing wildlife, smelling flowers or listening to birdsong). 


\subsection{Limitations and future directions}

Like most questionnaire surveys, our study has some limitations. First, although the survey was anonymous, social desirability bias remains possible. Second, we surveyed specific categories of people (i.e. dog-, cat- and non-pet owners) and therefore our conclusions could be restricted to this specific sample. However, we surveyed socio-demographically balanced samples of the population in three different countries, giving support for a potential generalization of our results. We acknowledge that using an online-survey, and distribution through panels of respondents have restricted the study to a subsample of the population (e.g. people with internet access). The crosscountry differences in EoN can be the result of a bias in climatic condition among countries. Our survey was disseminated in June, which is hot and dry in Israel compared with more pleasant weather in Europe and this can provide an alternative explanation for the differences we have identified in outdoor behaviors. Our measure of environmental knowledge was based on species identification skill, which is only one of the many facets of environmental knowledge, and we recognize that looking at another facet (e.g. a more general measure of biodiversity understanding) could have led to different results.

Although our approach did not allow for establishment of causality, due to the low response rate to dog shelter surveys, we did find that NR and environmental knowledge were strongly related to environmental attitudes. This is in line with previous studies showing that ecological behaviors are predicted by both environmental knowledge and connectedness to nature (Otto \& Pensini, 2017; Roczen, Kaiser, Bogner, \& Wilson, 2014), and that environmental attitudes are important predictors of environmental behaviors (Stern \& Dietz, 1994). We acknowledge that internal consistency of the NEP scale was relatively low in two countries, which might have affected the results. However, previous research has suggested connectedness to nature as a better predictor of environmental behaviors than NEP (Mayer \& Frantz, 2004; Whitburn, Linklater, \& Milfont, 2018). Hence, this, along with our result that pet ownership, and particularly dog ownership, through increased quantity of 
EoN, is associated with increased sense of belonging to the natural world, gives additional support for the indirect conservation value of owning a dog.

\section{Conclusion}

426

427

428

Reducing the biodiversity crisis largely depends on improving people's attitudes and behaviors towards nature, which are in turn largely threatened by the extinction of experience (Soga \& Gaston, 2016). Averting this deleterious phenomenon is therefore a key global and contemporary issue. We showed here that EoN, NR, environmental knowledge and attitudes significantly vary across countries and that these differences should be carefully considered when designing conservation interventions. We also showed that dog-ownership can help in reducing the extinction of experience, by directly influencing people's EoN and NR, and thus environmental attitudes, indirectly. However, our results suggest that, ultimately, enhancing opportunities to visit nature, by simply providing more green spaces, may not be sufficient to achieve conservation goals, and what is needed is to find ways to enhance the quality of EoN, and provide green spaces that deliver meaningful EoN.

To achieve this, landscape planners should develop programs that promote diverse, interactive and multisensory EoN that engage emotions and create more lasting memories (Clayton et al., 2017). Smartphone applications can also be useful to promote meaningful interactions with nature (e.g. 'iNaturalist' smartphone application; Newman et al., 2017), and provide for instance dog owners with friendly reminders to interact with nature - e.g. observe birds - while walking their dog. Creative design and gardening practices can also help promote interactions with nature: for instance by converting a portion of a public garden's lawn into a flowering prairie, so that people can benefit from the colorful blossom of multiple species, while using more intensively other portions of the lawn that are mowed; insect hotels or interactive bat billboards can facilitate interactions between humans and insects/bats, while providing habitats to these species; tiny road signs can also be crated to illustrate areas where wildlife is present but often remain unseen (Shwartz, 2018).

\section{References}


Amano, T., Butt, I., \& Peh, K. S.-H. (2018). The importance of green spaces to public health: a multicontinental analysis. Ecological Applications, O(0). https://doi.org/10.1002/eap.1748

Bamberg, S., \& Möser, G. (2007). Twenty years after Hines, Hungerford, and Tomera: A new metaanalysis of psycho-social determinants of pro-environmental behaviour. Journal of Environmental Psychology, 27(1), 14-25. https://doi.org/10.1016/j.jenvp.2006.12.002

Banks, P. B., \& Bryant, J. V. (2007). Four-legged friend or foe? Dog walking displaces native birds from natural areas. Biology Letters, 3(6), 611-613. https://doi.org/10.1098/rsbl.2007.0374

Bögeholz, S. (2006). Nature experience and its importance for environmental knowledge, values and action: recent German empirical contributions. Environmental Education Research, 12(1), 6584. https://doi.org/10.1080/13504620500526529

Brooks, T. M., Mittermeier, R. A., Mittermeier, C. G., Da Fonseca, G. A. B., Rylands, A. B., Konstant, W. R., ... Hilton-Taylor, C. (2002). Habitat Loss and Extinction in the Hotspots of Biodiversity. Conservation Biology, 16(4), 909-923. https://doi.org/10.1046/j.1523-1739.2002.00530.x

Buijs, A. E., Elands, B. H. M., \& Langers, F. (2009). No wilderness for immigrants: Cultural differences in images of nature and landscape preferences. Landscape and Urban Planning, 91(3), 113123. https://doi.org/10.1016/j.landurbplan.2008.12.003

Cardinale, B. J., Duffy, J. E., Gonzalez, A., Hooper, D. U., Perrings, C., Venail, P., ... Naeem, S. (2012). Biodiversity loss and its impact on humanity. Nature, 486(7401), 59-67. https://doi.org/10.1038/nature11148

CBS. (2017). Population Census - Central Bureau of Statistics. Retrieved November 26, 2017, from http://www.cbs.gov.il/census/census/main_mifkad08_e.html

Christian, H. E., Westgarth, C., Bauman, A., Richards, E. A., Rhodes, R. E., Evenson, K. R., ... Thorpe, R. J. (2013). Dog Ownership and Physical Activity: A Review of the Evidence. Journal of Physical Activity and Health, 10(5), 750-759. https://doi.org/10.1123/jpah.10.5.750 
Clayton, S., Colléony, A., Conversy, P., Maclouf, E., Martin, L., Torres, A.-C., ... Prévot, A.-C. (2017). Transformation of experience: Toward a new relationship with nature. Conservation Letters, 10(5), 645-651. https://doi.org/10.1111/conl.12337

Clayton, S., \& Myers, G. (2009). Conservation Psychology: Understanding and Promoting Human Care for Nature (Wiley-Blackwell).

Colléony, A., Clayton, S., Couvet, D., Saint Jalme, M., \& Prévot, A.-C. (2017). Human preferences for species conservation: Animal charisma trumps endangered status. Biological Conservation, 206, 263-269. https://doi.org/10.1016/j.biocon.2016.11.035

Colléony, A., Prévot, A.-C., Saint Jalme, M., \& Clayton, S. (2017). What kind of landscape management can counteract the extinction of experience? Landscape and Urban Planning, 159, 23-31. https://doi.org/10.1016/j.landurbplan.2016.11.010

Dallimer, M., Irvine, K. N., Skinner, A. M. J., Davies, Z. G., Rouquette, J. R., Maltby, L. L., .. Gaston, K. J. (2012). Biodiversity and the Feel-Good Factor: Understanding Associations between SelfReported Human Well-being and Species Richness. BioScience, 62(1), 47-55. https://doi.org/10.1525/bio.2012.62.1.9

Doherty, T. S., Dickman, C. R., Glen, A. S., Newsome, T. M., Nimmo, D. G., Ritchie, E. G., ... Wirsing, A. J. (2017). The global impacts of domestic dogs on threatened vertebrates. Biological Conservation, 210, Part A, 56-59. https://doi.org/10.1016/j.biocon.2017.04.007

Dunlap, R. E., Van Liere, K. D., Mertig, A. G., \& Jones, R. E. (2000). New Trends in Measuring Environmental Attitudes: Measuring Endorsement of the New Ecological Paradigm: A Revised NEP Scale. Journal of Social Issues, 56(3), 425-442. https://doi.org/10.1111/0022-4537.00176

Elliott, L. R., White, M. P., Taylor, A. H., \& Herbert, S. (2015). Energy expenditure on recreational visits to different natural environments. Social Science \& Medicine, 139, 53-60. https://doi.org/10.1016/j.socscimed.2015.06.038 
Franzen, A., \& Vogl, D. (2013). Two decades of measuring environmental attitudes: A comparative analysis of 33 countries. Global Environmental Change, 23(5), 1001-1008. https://doi.org/10.1016/j.gloenvcha.2013.03.009

Gairaud, M.-A. (2018, November 11). Parcs et jardins parisiens : attention, les règles vont changer. Le Parisien. Retrieved from http://www.leparisien.fr/paris-75/parcs-et-jardins-parisiensattention-les-regles-vont-changer-11-11-2018-7940100.php

Grajal, A., Luebke, J. F., Clayton, S., Kelly, L.-A. D., Karazsia, B. T., Saunders, C. D., ... Mann, M. E. (2016). The relationship between affective connections to animals and proenvironmental behaviors. Conservation Biology, 31(2), 322-330. https://doi.org/10.1111/cobi.12780

Keniger, L. E., Gaston, K. J., Irvine, K. N., \& Fuller, R. A. (2013). What are the Benefits of Interacting with Nature? International Journal of Environmental Research and Public Health, 10(3), 913935. https://doi.org/10.3390/ijerph10030913

Lail, P., McCormack, G. R., \& Rock, M. (2011). Does dog-ownership influence seasonal patterns of neighbourhood-based walking among adults? A longitudinal study. BMC Public Health, 11(1), 148. https://doi.org/10.1186/1471-2458-11-148

Lin, B. B., Fuller, R. A., Bush, R., Gaston, K. J., \& Shanahan, D. F. (2014). Opportunity or Orientation? Who Uses Urban Parks and Why. PLOS ONE, 9(1), e87422. https://doi.org/10.1371/journal.pone.0087422

Lindemann-Matthies, P. (2005). 'Loveable' mammals and 'lifeless' plants: how children's interest in common local organisms can be enhanced through observation of nature. International Journal of Science Education, 27, 655-677. https://doi.org/10.1080/09500690500038116

Mayer, F. S., \& Frantz, C. M. (2004). The connectedness to nature scale: A measure of individuals' feeling in community with nature. Journal of Environmental Psychology, 24(4), 503-515. https://doi.org/10.1016/j.jenvp.2004.10.001 
McDonald, J. L., Maclean, M., Evans, M. R., \& Hodgson, D. J. (2015). Reconciling actual and perceived rates of predation by domestic cats. Ecology and Evolution, 5(14), 2745-2753. https://doi.org/10.1002/ece3.1553

Miller, J. R. (2005). Biodiversity conservation and the extinction of experience. Trends in Ecology \& Evolution, 20(8), 430-434. https://doi.org/10.1016/j.tree.2005.05.013

Miller, J. R. (2006). Restoration, reconciliation, and reconnecting with nature nearby. Biological Conservation, 127(3), 356-361. https://doi.org/10.1016/j.biocon.2005.07.021

Newman, G., Chandler, M., Clyde, M., McGreavy, B., Haklay, M., Ballard, H., ... Gallo, J. (2017). Leveraging the power of place in citizen science for effective conservation decision making. Biological Conservation, 208, 55-64. https://doi.org/10.1016/j.biocon.2016.07.019

Nisbet, E. K., \& Zelenski, J. M. (2013). The NR-6: a new brief measure of nature relatedness. Frontiers in Psychology, 4. https://doi.org/10.3389/fpsyg.2013.00813

Nisbet, E. K., Zelenski, J. M., \& Murphy, S. A. (2009). The Nature Relatedness Scale: Linking Individuals' Connection With Nature to Environmental Concern and Behavior. Environment and Behavior, 41(5), 715-740. https://doi.org/10.1177/0013916508318748

Otto, S., \& Pensini, P. (2017). Nature-based environmental education of children: Environmental knowledge and connectedness to nature, together, are related to ecological behaviour. Global Environmental Change, 47, 88-94. https://doi.org/10.1016/j.gloenvcha.2017.09.009

Özgüner, H. (2011). Cultural Differences in Attitudes towards Urban Parks and Green Spaces. Landscape Research, 36(5), 599-620. https://doi.org/10.1080/01426397.2011.560474

Pett, T. J., Shwartz, A., Irvine, K. N., Dallimer, M., \& Davies, Z. G. (2016). Unpacking the PeopleBiodiversity Paradox: A Conceptual Framework. BioScience, biw036. https://doi.org/10.1093/biosci/biw036

Pilgrim, S. E., Cullen, L. C., Smith, D. J., \& Pretty, J. (2008). Ecological Knowledge is Lost in Wealthier Communities and Countries. Environmental Science \& Technology, 42(4), 1004-1009. https://doi.org/10.1021/es070837v 
R Core Team. (2013). R: A language and Environment for Statistical Computing. Vienna, Austria: R Foundation for Statistical Computing.

Randler, C. (2008). Teaching Species Identification - A Prerequisite for Learning Biodiversity and Understanding Ecology. Eurasia Journal of Mathematics, Science and Technology Education, 4(3), 223-231. https://doi.org/10.12973/ejmste/75344

Rands, M. R. W., Adams, W. M., Bennun, L., Butchart, S. H. M., Clements, A., Coomes, D., ... Vira, B. (2010). Biodiversity Conservation: Challenges Beyond 2010. Science, 329(5997), 1298-1303. https://doi.org/10.1126/science.1189138

Roczen, N., Kaiser, F. G., Bogner, F. X., \& Wilson, M. (2014). A Competence Model for Environmental Education. Environment and Behavior, 46(8), 972-992. https://doi.org/10.1177/0013916513492416

Schipperijn, J., Ekholm, O., Stigsdotter, U. K., Toftager, M., Bentsen, P., Kamper-Jørgensen, F., \& Randrup, T. B. (2010). Factors influencing the use of green space: Results from a Danish national representative survey. Landscape and Urban Planning, 95(3), 130-137. https://doi.org/10.1016/j.landurbplan.2009.12.010

Schutte, N. S., \& Malouff, J. M. (2018). Mindfulness and connectedness to nature: A meta-analytic investigation. Personality and Individual Differences, 127, 10-14. https://doi.org/10.1016/j.paid.2018.01.034

Schuttler, S. G., Sorensen, A. E., Jordan, R. C., Cooper, C., \& Shwartz, A. (2018). Bridging the nature gap: can citizen science reverse the extinction of experience? Frontiers in Ecology and the Environment, O(0). https://doi.org/10.1002/fee.1826

Seto, K. C., Güneralp, B., \& Hutyra, L. R. (2012). Global forecasts of urban expansion to 2030 and direct impacts on biodiversity and carbon pools. Proceedings of the National Academy of Sciences, 109(40), 16083-16088. https://doi.org/10.1073/pnas.1211658109 
Shanahan, D. F., Bush, R., Gaston, K. J., Lin, B. B., Dean, J., Barber, E., \& Fuller, R. A. (2016). Health Benefits from Nature Experiences Depend on Dose. Scientific Reports, 6, 28551. https://doi.org/10.1038/srep28551

Shanahan, D. F., Fuller, R. A., Bush, R., Lin, B. B., \& Gaston, K. J. (2015). The Health Benefits of Urban Nature: How Much Do We Need? BioScience, biv032. https://doi.org/10.1093/biosci/biv032 Shwartz, A. (2018). Designing Nature in Cities to Safeguard Meaningful Experiences of Biodiversity in an Urbanizing World. In Urban biodiversity - From research to practice (pp. 200-215). ROUTLEDGE \& GSE Research. https://doi.org/info:doi/10.9774/GLEAF.9781315402581_14

Shwartz, A., Cheval, H., Simon, L., \& Julliard, R. (2013). Virtual Garden Computer Program for use in Exploring the Elements of Biodiversity People Want in Cities. Conservation Biology, 27(4), 876-886. https://doi.org/10.1111/cobi.12057

Soga, M., \& Gaston, K. J. (2016). Extinction of experience: the loss of human-nature interactions. Frontiers in Ecology and the Environment, 14(2), 94-101. https://doi.org/10.1002/fee.1225

Soga, M., Gaston, K. J., Koyanagi, T. F., Kurisu, K., \& Hanaki, K. (2016). Urban residents' perceptions of neighbourhood nature: Does the extinction of experience matter? Biological Conservation, 203, 143-150. https://doi.org/10.1016/j.biocon.2016.09.020

Soga, M., Yamaura, Y., Aikoh, T., Shoji, Y., Kubo, T., \& Gaston, K. J. (2015). Reducing the extinction of experience: Association between urban form and recreational use of public greenspace. Landscape and Urban Planning, 143, 69-75. https://doi.org/10.1016/j.landurbplan.2015.06.003

Stern, P. C., \& Dietz, T. (1994). The Value Basis of Environmental Concern. Journal of Social Issues, 50(3), 65-84. https://doi.org/10.1111/j.1540-4560.1994.tb02420.x

Stern, P. C., Dietz, T., Abel, T., Guagnano, G. A., \& Kalof, L. (1999). A Value-Belief-Norm Theory of Support for Social Movements: The Case of Environmentalism. Human Ecology Review, 6(2), $81-97$. 
Tam, K.-P. (2013). Concepts and measures related to connection to nature: Similarities and differences. Journal of Environmental Psychology, 34, 64-78. https://doi.org/10.1016/j.jenvp.2013.01.004

Toohey, A. M., \& Rock, M. J. (2011). Unleashing their potential: a critical realist scoping review of the influence of dogs on physical activity for dog-owners and non-owners. International Journal of Behavioral Nutrition and Physical Activity, 8, 46. https://doi.org/10.1186/1479-5868-8-46

Wells, N. M., \& Lekies, K. S. (2006). Nature and the Life Course: Pathways from Childhood Nature Experiences to Adult Environmentalism. Children, Youth and Environments, 16(1), 1-24.

Whitburn, J., Linklater, W. L., \& Milfont, T. L. (2018). Exposure to Urban Nature and Tree Planting Are Related to Pro-Environmental Behavior via Connection to Nature, the Use of Nature for Psychological Restoration, and Environmental Attitudes. Environment and Behavior, 0013916517751009. https://doi.org/10.1177/0013916517751009

White, M. P., Elliott, L. R., Taylor, T., Wheeler, B. W., Spencer, A., Bone, A., .. Fleming, L. E. (2016). Recreational physical activity in natural environments and implications for health: A population based cross-sectional study in England. Preventive Medicine, 91, 383-388. https://doi.org/10.1016/j.ypmed.2016.08.023

White, M. P., Elliott, L. R., Wheeler, B. W., \& Fleming, L. E. (2018). Neighbourhood greenspace is related to physical activity in England, but only for dog owners. Landscape and Urban Planning, 174, 18-23. https://doi.org/10.1016/j.landurbplan.2018.01.004

White, R. L., Eberstein, K., \& Scott, D. M. (2018). Birds in the playground: Evaluating the effectiveness of an urban environmental education project in enhancing school children's awareness, knowledge and attitudes towards local wildlife. PLOS ONE, 13(3), e0193993. https://doi.org/10.1371/journal.pone.0193993

Wood, L., Giles-Corti, B., \& Bulsara, M. (2005). The pet connection: Pets as a conduit for social capital? Social Science \& Medicine, 61(6), 1159-1173. https://doi.org/10.1016/j.socscimed.2005.01.017 
621 Wood, L., Martin, K., Christian, H., Nathan, A., Lauritsen, C., Houghton, S., ... McCune, S. (2015). The Pet Factor - Companion Animals as a Conduit for Getting to Know People, Friendship Formation and Social Support. PLOS ONE, 10(4), e0122085. https://doi.org/10.1371/journal.pone.0122085 
627 Table 1: Effect sizes and standard errors of minimum adequate linear models explaining EoN 628 (frequency of visits, number of places) for the online survey $(N=741)$. Significance levels are shown: * $\mathrm{p}<0.05,{ }^{* *} \mathrm{p}<0.01,{ }^{* * *} \mathrm{p}<0.001$. Empty cells are for variables that were omitted during the model selection process. If a variable was omitted during the model selection process for both models, it was not reported in the table.

Table 2: Effect sizes and standard errors of minimum adequate linear models explaining NR, environmental knowledge, environmental attitudes (NEP), and awareness of the impact of dogs and cats on biodiversity, respectively, for the online survey $(N=741)$. Significance levels are shown: * $\mathrm{p}<0.05,{ }^{* *} \mathrm{p}<0.01,{ }^{* * *} \mathrm{p}<0.001$. Empty cells are for variables that were omitted during the model selection process. If a variable was omitted during the model selection process for all models, it was not reported in the table. 
Table 1

\begin{tabular}{|c|c|c|c|}
\hline & & 1 - Frequency of visits & 2 - Number of places \\
\hline Intercept & & $0.29 \pm 0.07^{* * *}$ & $-0.08 \pm 0.18$ \\
\hline Pet & $\begin{array}{l}\text { Dog (reference) } \\
\text { Cat } \\
\text { No pet }\end{array}$ & $\begin{array}{c}- \\
-0.36 \pm 0.08^{* * *} \\
-0.45 \pm 0.07^{* * *}\end{array}$ & $\begin{array}{c}- \\
-0.18 \pm 0.08^{*} \\
-0.26 \pm 0.08^{* *}\end{array}$ \\
\hline NR & & $0.36 \pm 0.05^{* * *}$ & $0.26 \pm 0.05^{* * *}$ \\
\hline Country & $\begin{array}{l}\text { France (reference) } \\
\text { Israel } \\
\text { UK }\end{array}$ & $\begin{array}{c}- \\
-0.26 \pm 0.08^{* * *} \\
0.05 \pm 0.07\end{array}$ & $\begin{array}{c}- \\
-0.29 \pm 0.09^{* *} \\
0.09 \pm 0.08\end{array}$ \\
\hline Current urbanization & & $-0.10 \pm 0.03^{* *}$ & \\
\hline Age & $\begin{array}{l}18-24 \text { (reference) } \\
25-34 \\
35-44 \\
45-54 \\
55-64 \\
65+\end{array}$ & & $\begin{array}{l}- \\
-0.19 \pm 0.11 \\
-0.14 \pm 0.11 \\
-0.51 \pm 0.11^{* * *} \\
-0.43 \pm 0.12^{* * *} \\
-0.35 \pm 0.14^{*}\end{array}$ \\
\hline Education & $\begin{array}{l}\text { Below High School (reference) } \\
\text { High School } \\
\text { Professional diploma } \\
\text { First degree } \\
\text { Second degree } \\
\text { Third degree }\end{array}$ & & \begin{tabular}{l}
\multicolumn{1}{c}{$\quad-$} \\
$0.39 \pm 0.16^{*}$ \\
$0.57 \pm 017^{* * *}$ \\
$0.61 \pm 0.16^{* * *}$ \\
$0.60 \pm 0.18^{* * *}$ \\
$0.61 \pm 0.23^{* *}$ \\
\end{tabular} \\
\hline NR : Country & $\begin{array}{l}\text { France (reference) } \\
\text { Israel } \\
\text { UK }\end{array}$ & $\begin{array}{c}- \\
-0.27 \pm 0.08^{* *} \\
0.06 \pm 0.07\end{array}$ & \\
\hline
\end{tabular}




\begin{tabular}{|c|c|c|c|c|c|c|}
\hline & & $\begin{array}{l}3 \text { - Nature } \\
\text { relatedness }\end{array}$ & $\begin{array}{c}4- \\
\text { Environmental } \\
\text { knowledge }\end{array}$ & $\begin{array}{l}5- \\
\text { Environmental } \\
\text { attitudes (NEP) }\end{array}$ & $\begin{array}{l}6 \text { - Awareness of } \\
\text { the impact of dogs }\end{array}$ & $\begin{array}{l}7 \text { - Awareness of } \\
\text { the impact of cats }\end{array}$ \\
\hline Intercept & & $-0.02 \pm 0.18$ & $-0.35 \pm 0.09^{* * *}$ & $0.26 \pm 0.07^{* * *}$ & $-0.26 \pm 0.21$ & $-0.32 \pm 0.21$ \\
\hline NR & & Not in model & $0.14 \pm 0.04^{* * *}$ & $0.17 \pm 0.04^{* * *}$ & & \\
\hline Current urbanization & & & $-0.08 \pm 0.04^{*}$ & & & \\
\hline Age & $\begin{array}{l}18-24 \text { (reference) } \\
25-34 \\
35-44 \\
45-54 \\
55-64 \\
65+\end{array}$ & \begin{tabular}{l}
\multicolumn{1}{c}{$\quad-$} \\
$0.16 \pm 0.11$ \\
$0.40 \pm 0.12^{* * *}$ \\
$0.33 \pm 0.12^{* *}$ \\
$0.17 \pm 0.12$ \\
$0.29 \pm 0.14^{*}$
\end{tabular} & \begin{tabular}{l}
\multicolumn{1}{c}{-} \\
$0.04 \pm 0.13$ \\
$0.33 \pm 0.15^{*}$ \\
$0.29 \pm 0.14^{*}$ \\
$0.73 \pm 0.13^{* * *}$ \\
$0.84 \pm 0.15^{* * *}$
\end{tabular} & & & \\
\hline Knowledge: Country & $\begin{array}{l}\text { France (reference) } \\
\text { Israel } \\
\text { UK }\end{array}$ & & & & \begin{tabular}{l}
\multicolumn{1}{c}{-} \\
$0.27 \pm 0.14$ \\
$0.44 \pm 0.10^{* * *}$
\end{tabular} & \begin{tabular}{l}
\multicolumn{1}{c}{-} \\
$0.29 \pm 0.14^{*}$ \\
$0.33 \pm 0.10^{* *}$
\end{tabular} \\
\hline
\end{tabular}


643 Figure 1: Pathways from experiences of nature to pro-environmental behaviors, based on Clayton and Myers (2009). (a) Experiences of nature are a central foundation for sense of belonging to the natural world (can be measured through nature relatedness) and knowledge about it, which in turn can lead to stronger pro-environmental attitudes that can translate into pro-environmental behaviors if triggered. (b) Pathways from experiences of nature to pro-environmental behaviors can be affected by external factors, such as pets. These pathways are expected to vary between cat and dog owners, as dogs, unlike cats, motivate people to go out more often. Ultimately, increased pro-environmental attitudes and behaviors could help mitigate direct negative impact of pets on biodiversity. Solid lines represent hypotheses tested in this study. Dashed lines represent assumptions building on previous research that we do not directly test in this paper. EoN = Experiences of nature; Connect. Animal = Connection to the animal; Env. Attitudes = Environmental attitudes; Env. Behaviors = Environmental behaviors. "+" indicates a positive relationship, while "-" indicates a negative one; number of "+" indicates strength of the relationship. Drawings of people and animals were taken from Pixabay 656 (Creative Commons CCO).

Figure 2: Significant variation of (a) frequency of visits (from 1 Never to 5 Everyday) and (b) number of places (up to 7), between dog owners, cat owners and non-pet owners from the online survey $(\mathrm{N}=741)$. Adjusted means and standard errors from the linear models are displayed. Significant differences from the ANOVAs and post-hoc Tukey tests are shown with different letters: $a$ is significantly different from b. Drawings of animals were taken from Pixabay (Creative Commons CCO).

Figure 3: Variation in average scores of experiences of nature (frequency of visits and number of places), nature relatedness, environmental knowledge and environmental attitudes between France, Israel and the UK, based on the online survey ( $\mathrm{N}=741)$. Means and standard deviations (in brackets) are given for each country. Significance levels are shown: ${ }^{*} p<0.05,{ }^{* *} p<0.01,{ }^{* * *} p<0.001$, 668 according to Tukey HSD post-hoc tests. 


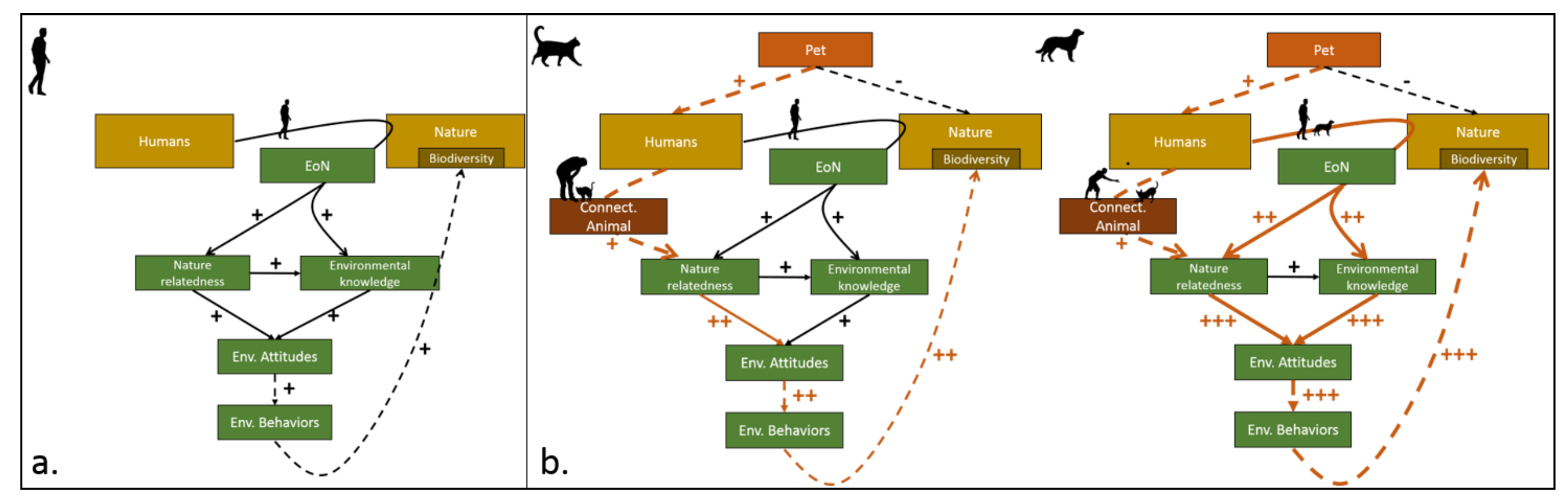

$671 \quad$ Figure 1 
(a)

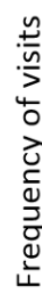

673

674

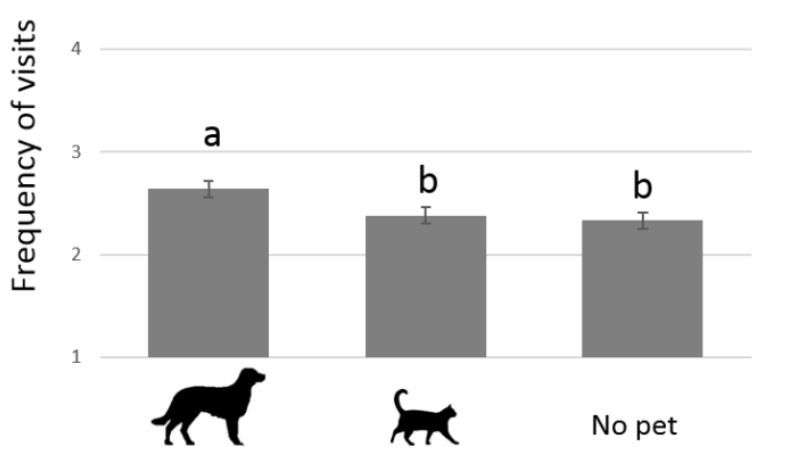

Dog owners fenct Cat owners (b)

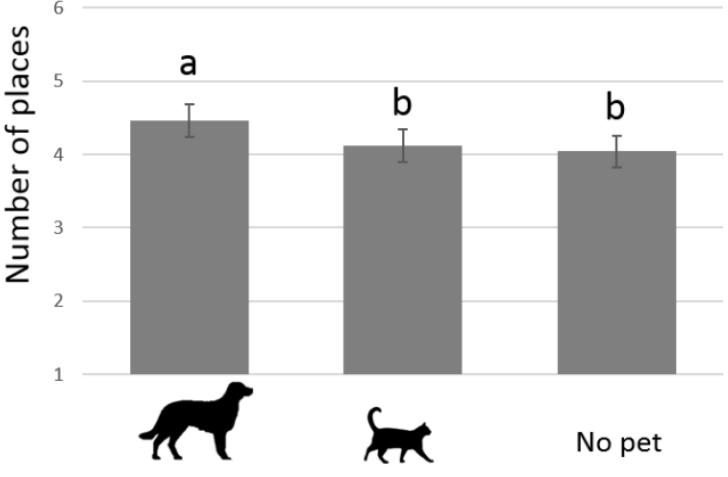

No pet Non-pet owners

Figure 2 


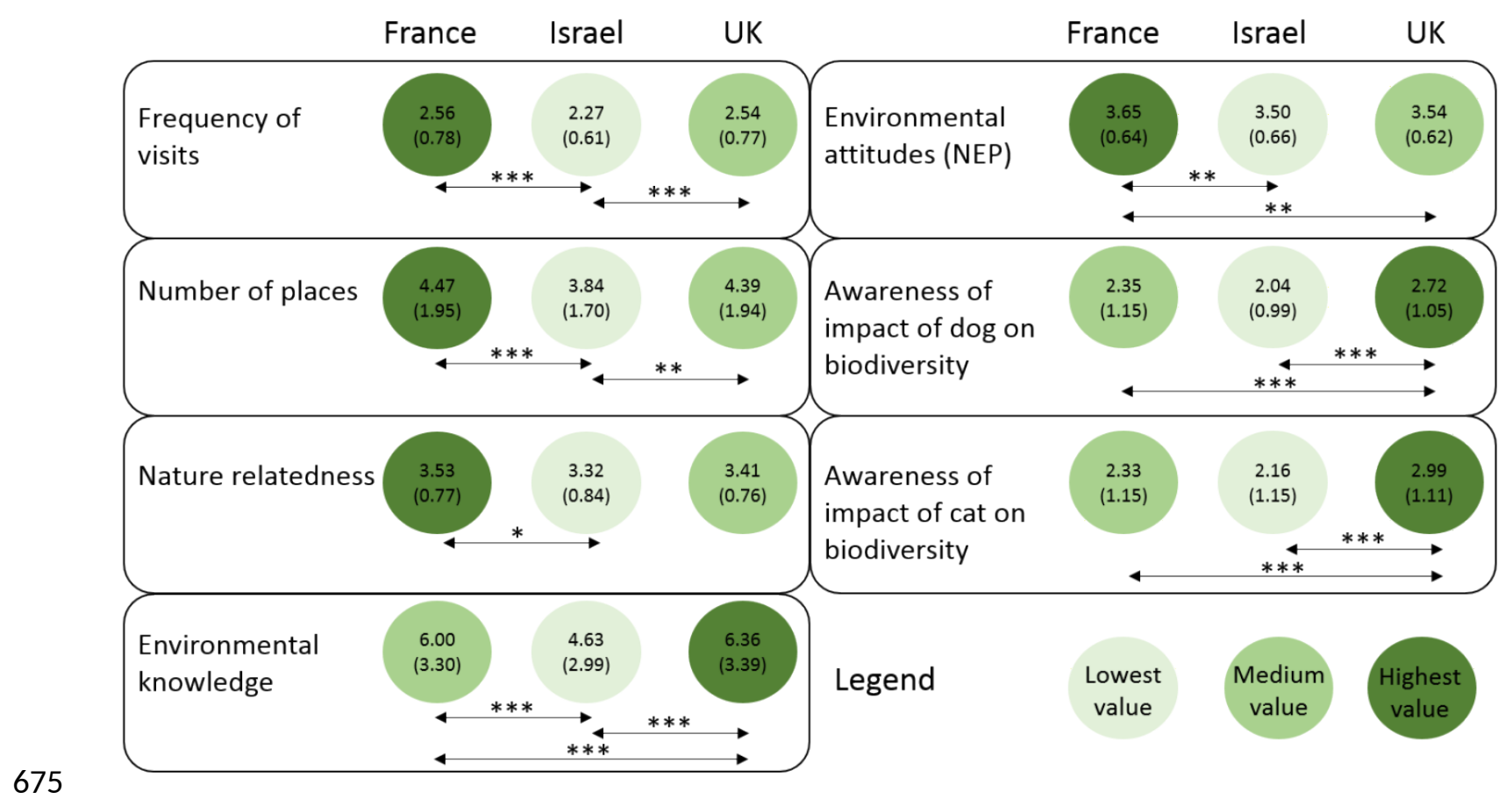

\section{$676 \quad$ Figure 3}

677

678

679 


\section{Acknowledgements}

2 We wish to thank D. Bashan for her help in translating the questionnaires in Hebrew and recruiting

3 the participating dog shelters in Israel. We also thank R. Cohen for her help keeping in touch with

4 participating dog shelters in Israel. H. Segre assisted by coding Hebrew responses for environmental

5 knowledge questions. Finally, we are grateful to all managers of the dog shelters for their

6 participation in the project. This research was funded by the Israel Science Foundation (Grant No.

7 1456/16) and A.C. was also partly supported by the Technion Fellowship for distinguished

8 postdoctoral fellows.

9 


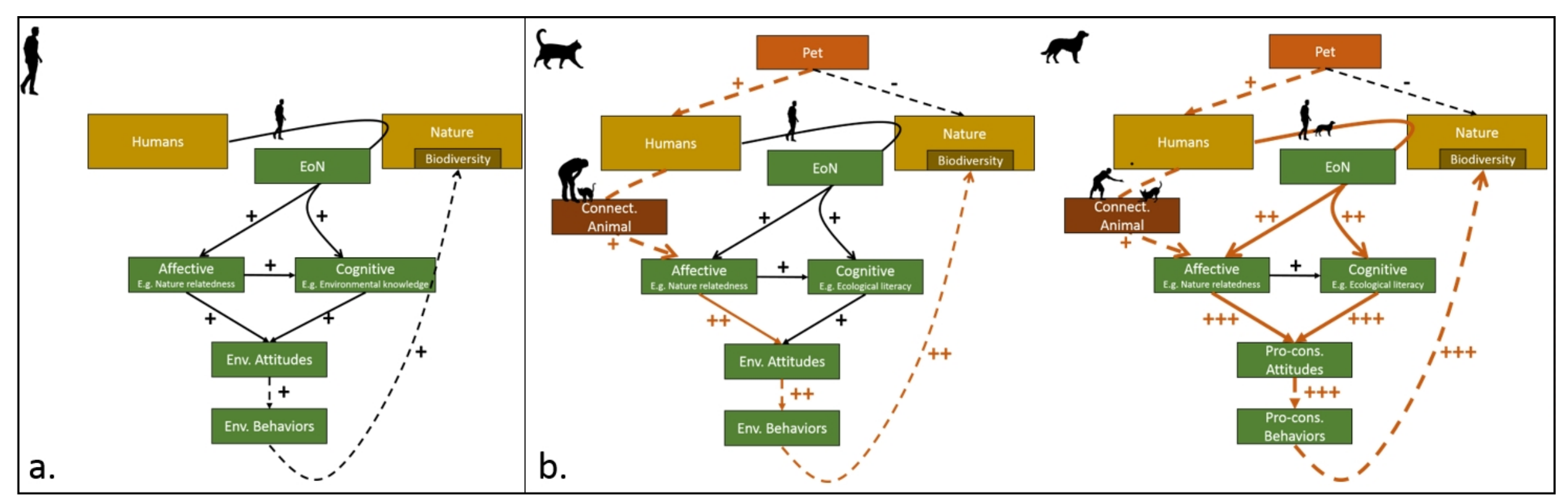


(a)

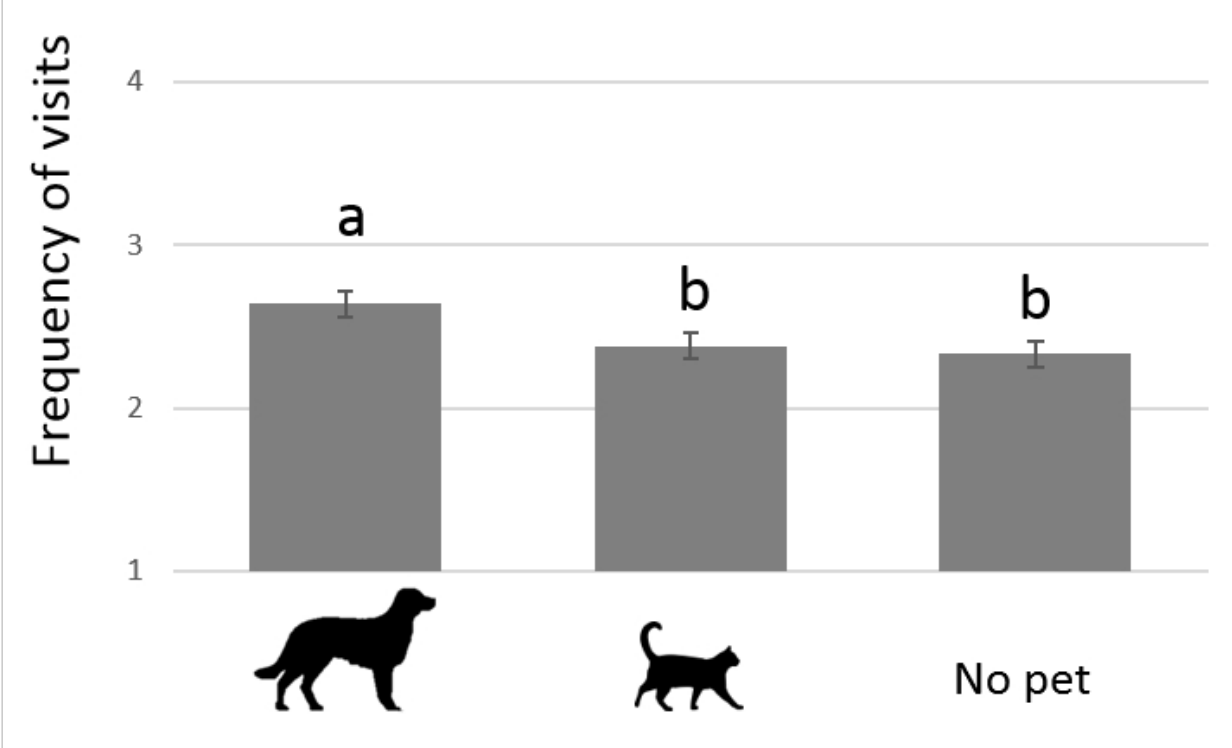

Dog owners Cat owners No pet Non-pet owners (b)

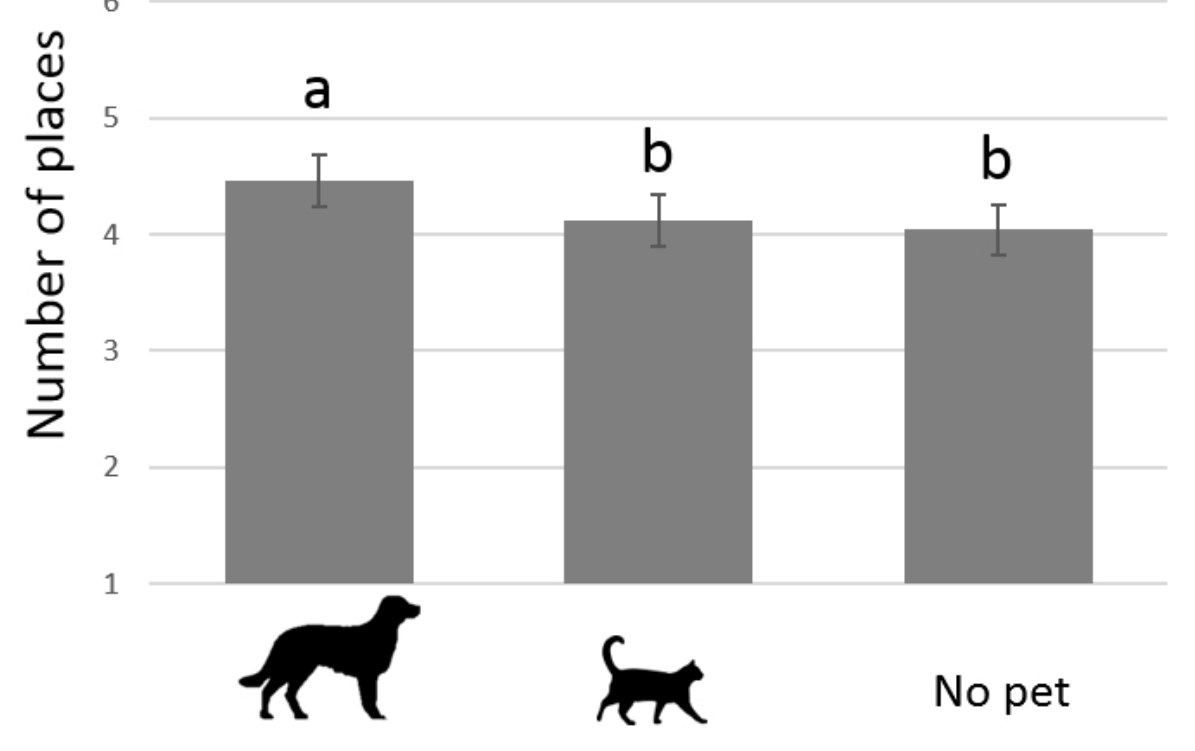




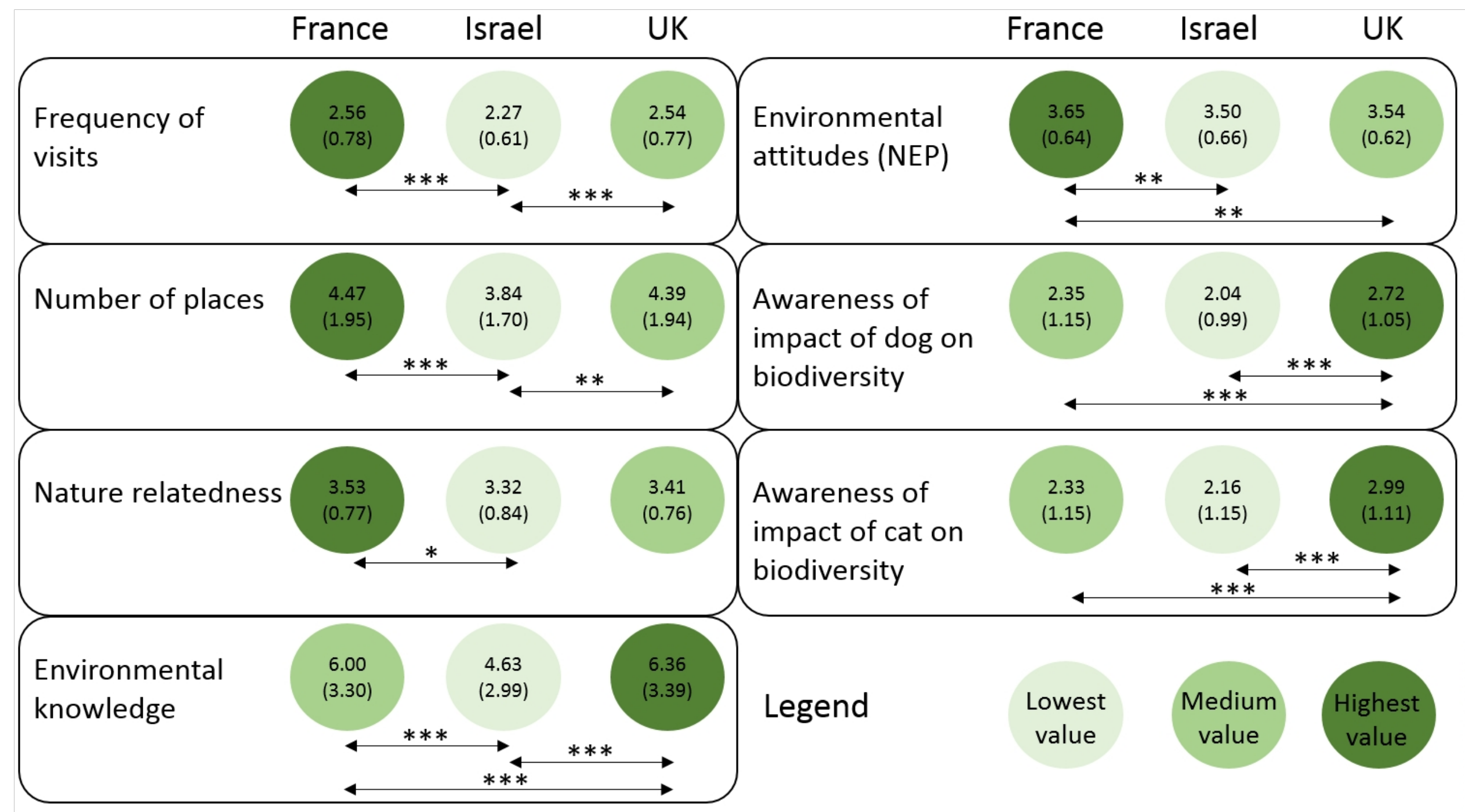




\section{APPENDICES}

\section{Appendix A}

Table A1: Demographics of survey respondents (proportions are given in brackets).

Table A2: Description of the items used to determine frequency of visits, urbanization level and environmental knowledge.

Figure A1: Interaction effects of country between (a) frequency of visits and NR, (b) number of places visited and NR, (c) awareness of the impact of dogs on biodiversity and environmental knowledge, and (d) awareness of the impact of cats on biodiversity and environmental knowledge. Red lines: France; green lines: Israel; and blue lines: UK.

\section{Appendix B}

Survey B1: Questionnaire for the online survey

Survey B2: Questionnaire for the 'before adoption' survey in dog shelters

Survey B3: Questionnaire for the 'after adoption' survey in dog shelters 
Table A1

Demographics of survey respondents (proportions are given in brackets).

\begin{tabular}{|c|c|c|c|c|}
\hline & & France & Israel & UK \\
\hline \multirow[t]{3}{*}{ Pet ownership } & Dog & $101(39 \%)$ & $60(34 \%)$ & 102 (33\%) \\
\hline & Cat & $83(32 \%)$ & $43(25 \%)$ & $66(21 \%)$ \\
\hline & No pet & $73(28 \%)$ & $71(41 \%)$ & $141(46 \%)$ \\
\hline \multirow[t]{2}{*}{ Gender } & Men & $134(52 \%)$ & 85 (49\%) & $144(47 \%)$ \\
\hline & Women & $123(48 \%)$ & $89(51 \%)$ & 165 (53\%) \\
\hline \multirow[t]{6}{*}{ Age } & $18-24$ & $68(27 \%)$ & $18(10 \%)$ & 39 (13\%) \\
\hline & $25-34$ & $52(20 \%)$ & $71(41 \%)$ & $53(17 \%)$ \\
\hline & $35-44$ & $41(16 \%)$ & $44(25 \%)$ & $42(14 \%)$ \\
\hline & $45-54$ & 31 (12\%) & 38 (22\%) & 52 (17\%) \\
\hline & $55-64$ & 45 (18\%) & $1(1 \%)$ & $70(23 \%)$ \\
\hline & $65+$ & $20(8 \%)$ & $2(1 \%)$ & $53(17 \%)$ \\
\hline \multirow[t]{6}{*}{ Level of education } & Below high school & $22(9 \%)$ & $2(1 \%)$ & $11(4 \%)$ \\
\hline & High school & $56(22 \%)$ & $40(23 \%)$ & $111(36 \%)$ \\
\hline & Professional diploma & $42(16 \%)$ & $30(17 \%)$ & $68(22 \%)$ \\
\hline & First degree & $67(26 \%)$ & $72(42 \%)$ & $83(27 \%)$ \\
\hline & Second degree & $55(21 \%)$ & $24(14 \%)$ & $27(9 \%)$ \\
\hline & Third degree & $15(6 \%)$ & $4(2 \%)$ & $9(3 \%)$ \\
\hline \multirow[t]{4}{*}{$\begin{array}{l}\text { Urbanization level of } \\
\text { current residence }\end{array}$} & Hamlet & $\begin{array}{l}11(4.2 \%) \\
\text { (Dog: 4; Cat: } \\
\text { 4; No pet: 3) }\end{array}$ & $\begin{array}{l}14 \text { (8\%) } \\
\text { (Dog: 5; } \\
\text { Cat: 5; No } \\
\text { pet: 4) }\end{array}$ & $\begin{array}{l}16 \text { (5.1\%) } \\
\text { (Dog: 6; Cat: 5; } \\
\text { No pet: 5) }\end{array}$ \\
\hline & Village & $\begin{array}{l}74 \text { (28.6\%) } \\
\text { (Dog: 37; Cat: } \\
\text { 25; No pet: } \\
\text { 12) }\end{array}$ & $\begin{array}{l}15 \text { (8.6\%) } \\
\text { (Dog: 6; } \\
\text { Cat: 5; No } \\
\text { pet: 4) }\end{array}$ & $\begin{array}{l}66 \text { (21.3\%) } \\
\text { (Dog: 22; Cat: } \\
\text { 16; No pet: 28) }\end{array}$ \\
\hline & $\begin{array}{l}\text { Town or medium size } \\
\text { city }\end{array}$ & $\begin{array}{l}84 \text { (32.5\%) } \\
\text { (Dog: 29; Cat: } \\
\text { 23; No pet: } \\
\text { 32) }\end{array}$ & $\begin{array}{l}62(35.6 \%) \\
\text { (Dog: 20; } \\
\text { Cat: 14; No } \\
\text { pet: 28) }\end{array}$ & $\begin{array}{l}172 \text { (55.6\%) } \\
\text { (Dog: 58; Cat: } \\
\text { 32; No pet: 82) }\end{array}$ \\
\hline & Large city & $\begin{array}{l}88 \text { (34.1\%) } \\
\text { (Dog: 31; Cat: } \\
\text { 31; No pet: } \\
\text { 26) }\end{array}$ & $\begin{array}{l}83(47.7 \%) \\
\text { (Dog: } 29 ; \\
\text { Cat: } 19 ; \text { No } \\
\text { pet: } 35 \text { ) }\end{array}$ & $\begin{array}{l}55 \text { (17.7\%) } \\
\text { (Dog: 16; Cat: } \\
\text { 13; No pet: 26) }\end{array}$ \\
\hline
\end{tabular}




\section{Table A2}

Description of the items used to determine frequency of visits, urbanization level and environmental knowledge.

\begin{tabular}{|c|c|}
\hline $\begin{array}{l}\text { Seven } \\
\text { different } \\
\text { types of } \\
\text { places }\end{array}$ & $\begin{array}{l}\text { 'private garden', 'road/street', 'urban park or other public/urban greenspace', } \\
\text { 'forest/woodland', 'agricultural areas (e.g. meadow, agricultural field)', 'beach', } \\
\text { and 'water bodies (e.g. lake, river)' }\end{array}$ \\
\hline $\begin{array}{l}\text { Urbanization } \\
\text { level }\end{array}$ & 1: Hamlet, 2: Village, 3: Town or medium size city, 4: Large city \\
\hline $\begin{array}{l}\text { Environmental } \\
\text { knowledge }\end{array}$ & $\begin{array}{l}\text { Following Dallimer et al. (2012), we selected species that are very common in } \\
\text { each country, and that can be observed in a broad range of habitats. Specifically, } \\
\text { we selected four bird species: the rock dove (Columba livia), great tit (Parus } \\
\text { major), common blackbird (Turdus merula), and house sparrow (Passer } \\
\text { domesticus). For French and UK respondents, selected butterfly species were the } \\
\text { large white (Pieris brassicae), painted lady (Vanessa cardui), common brimstone } \\
\text { (Gonepteryx rhamni), red admiral (Vanessa atalanta); for Israeli respondents, the } \\
\text { common brimstone (G. rhamni) was replaced by the cleopatra butterfly (G. } \\
\text { cleopatra). The four selected plant species for French and UK respondents were } \\
\text { the common daisy (Bellis perennis), the creeping buttercup (Ranunculus repens), } \\
\text { field forget-me-not (Myosotis arvensis) and common poppy (Papaver rhoeas). For } \\
\text { Israel, common and similar plant species to those selected for the French and UK } \\
\text { respondents were selected: southern daisy (B. sylvestris), eastern groundsel } \\
\text { (Senecio vernalis), scarlet pimpernel (Anagallis arvensis), semitic poppy (P. } \\
\text { umbonatum). This method was previously piloted and validated in Israel with } \\
\text { more than } 900 \text { participants (Tzunz, 2017) }\end{array}$ \\
\hline
\end{tabular}

Clayton, S., \& Myers, G. (2009). Conservation Psychology: Understanding and Promoting Human Care for Nature (Wiley-Blackwell).

Dallimer, M., Irvine, K. N., Skinner, A. M. J., Davies, Z. G., Rouquette, J. R., Maltby, L. L., ... Gaston, K. J. (2012). Biodiversity and the Feel-Good Factor: Understanding Associations between SelfReported Human Well-being and Species Richness. BioScience, 62(1), 47-55. https://doi.org/10.1525/bio.2012.62.1.9

Tzunz, M. (2017). Relationship between people and biodiversity in public gardens: a case study in Netanya (Master Thesis). Technion - Israel Institute of Technology, Haifa, Israel. 


\section{Figure A1}

Interaction effects of country between (a) frequency of visits and NR, (b) number of places visited and NR, (c) awareness of the impact of dogs on biodiversity and environmental knowledge, and (d) awareness of the impact of cats on biodiversity and environmental knowledge. Red lines: France; green lines: Israel; and blue lines: UK.

(a)

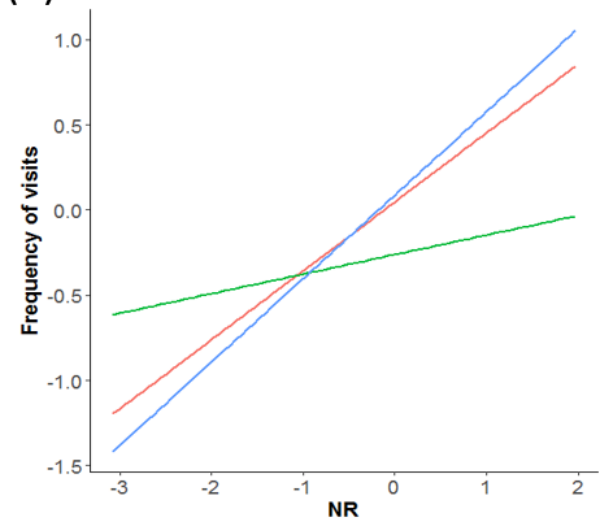

(c)

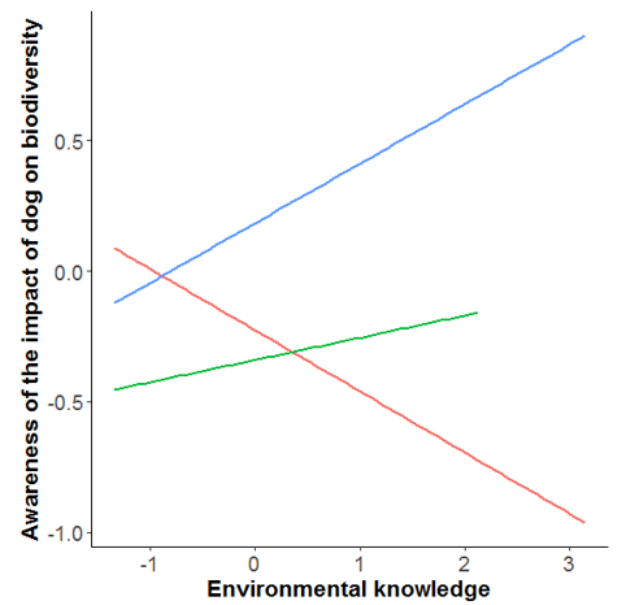

(b)

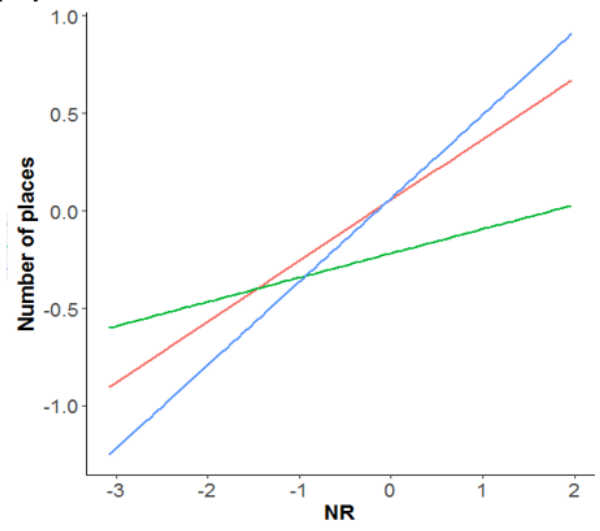

(d)

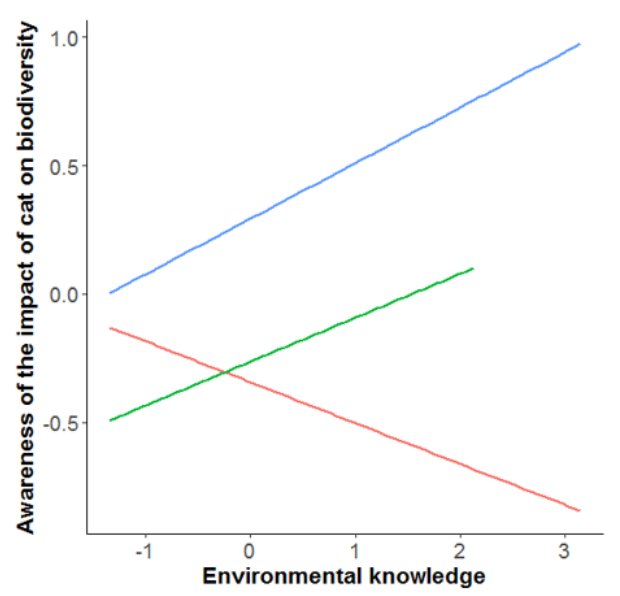




\title{
Survey B1: Online Questionnaire
}

\author{
Dear Participant,
}

You are invited to take part in a survey that investigates people's use of urban space with/without a pet. The questionnaire will take about 10 minutes to complete.

Your responses will be anonymous. Data will be stored in a secured file. There is no risk in taking part in this survey and there are no good or bad answers; we are simply interested in your opinion on the following matters regarding people's use of urban space with/without pet. The information gathered will only be used for research purposes.

As you are registered within a panel of respondents, you will receive incentives in exchange for participation in this survey also.

Should you have any further questions about this project or if you have a problem of any kind, you may contact the principle investigator [blinded for review].

By choosing to participate, you are confirming that you are 18 years of age or older, that you have read and understand the information provided above and that you willingly choose to participate in this survey. If you choose to participate, please tick I ACCEPT.

Thank you

I accept (1)

I do not accept (2) 
Are you:

A man? (1)
A woman? (2)

What is your age?

$18-24(1)$

25-34 (2)

$35-44(3)$

45-54 (4)

$55-64(5)$

$65+(6)$

In your household, do you currently have:

A dog - How many? (1)

A cat - How many? (2)

Another pet (3)

No pet (4) 
Where are you currently living?

France (1)

Israel (2)

UK (3)

Other country (4)

For each place listed below, please indicate the extent to which you visited it for leisure, in the past month.

\begin{tabular}{|l|l|l|l|l|l|}
\hline \multicolumn{2}{|c|}{} & \multicolumn{3}{|c|}{ Frequency of visits } \\
\hline & $\begin{array}{l}\text { 0 - Did not } \\
\text { visit last } \\
\text { month (1) }\end{array}$ & $\begin{array}{l}\text { 1 - Less than } \\
\text { once a week } \\
\text { (2) }\end{array}$ & $\begin{array}{l}\text { 2 Once a } \\
\text { week (3) }\end{array}$ & $\begin{array}{l}\text { 3 - Several } \\
\text { times a week } \\
\text { (4) }\end{array}$ & $\begin{array}{l}\text { 4 - Everyday } \\
\text { (5) }\end{array}$ \\
\hline Road/Street (1) & & & & & \\
\hline $\begin{array}{l}\text { Private garden } \\
\text { (2) }\end{array}$ & & & & & \\
\hline $\begin{array}{l}\text { Urban park or } \\
\text { other } \\
\text { public/urban } \\
\text { greenspace (3) }\end{array}$ & & & & & \\
\hline $\begin{array}{l}\text { Woodland/Forest } \\
\text { (4) }\end{array}$ & & & & & \\
\hline $\begin{array}{l}\text { Agricultural area } \\
\text { (e.g. meadow, } \\
\text { agricultural field) } \\
\text { (5) }\end{array}$ & & & & & \\
\hline Beach (6) & & & & & \\
\hline $\begin{array}{l}\text { Water bodies } \\
\text { (e.g. lake, river) } \\
\text { (7) }\end{array}$ & & & & & \\
\hline
\end{tabular}


For each of the following, please rate the extent to which you agree with each statement. Please respond as you really feel, rather than how you think "most people" feel.

\begin{tabular}{|c|c|c|c|c|c|}
\hline & $\begin{array}{l}1 \text { - Strongly } \\
\text { disagree (1) }\end{array}$ & $\begin{array}{c}2- \\
\text { Disagree } \\
\quad(2)\end{array}$ & $\begin{array}{l}\text { 3- Neither } \\
\text { Agree or } \\
\text { Disagree (3) }\end{array}$ & $\begin{array}{l}\text { 4- Agree } \\
\text { (4) }\end{array}$ & $\begin{array}{l}5- \\
\text { Strongly } \\
\text { agree (5 }\end{array}$ \\
\hline \multicolumn{6}{|l|}{$\begin{array}{l}\text { My ideal vacation spot would be a } \\
\text { remote, wilderness area (1) }\end{array}$} \\
\hline $\begin{array}{l}\text { I always think about how my actions } \\
\text { affect the environment (2) }\end{array}$ & & C & 0 & $\checkmark$ & \\
\hline \multicolumn{6}{|l|}{$\begin{array}{l}\text { My connection to nature and the } \\
\text { environment is a part of my } \\
\text { spirituality (3) }\end{array}$} \\
\hline \multicolumn{6}{|l|}{$\begin{array}{l}\text { I take notice of wildlife wherever I } \\
\qquad \text { am (4) }\end{array}$} \\
\hline \multicolumn{6}{|l|}{$\begin{array}{l}\text { My relationship to nature is an } \\
\text { important part of who I am (5) }\end{array}$} \\
\hline $\begin{array}{l}\text { I feel very connected to all living } \\
\text { things and the earth (6) }\end{array}$ & & & & & \\
\hline
\end{tabular}

If you have more than one cat, please answer the following questions regarding the cat of your choice.

For how long have you had your cat?

Do you walk your cat outside?

Yes (1)

No (2) 
For each place listed, please indicate the extent to which you visited it with your cat in the past month.

\begin{tabular}{|l|l|l|l|l|l|}
\hline & \multicolumn{5}{|c|}{ Frequency of visits } \\
\hline & $\begin{array}{l}\text { 0 - Did not } \\
\text { visit last } \\
\text { month (1) }\end{array}$ & $\begin{array}{l}\text { 1 - Less than } \\
\text { once a week } \\
\text { (2) }\end{array}$ & $\begin{array}{l}\text { 2 - Once a } \\
\text { week (3) }\end{array}$ & $\begin{array}{l}\text { 3 - Several } \\
\text { times a week } \\
\text { (4) }\end{array}$ & $\begin{array}{l}\text { 4 - Everyday } \\
\text { (5) }\end{array}$ \\
\hline Road/Street (1) & & & & & \\
\hline $\begin{array}{l}\text { Private garden } \\
\text { (2) }\end{array}$ & & & & & \\
\hline $\begin{array}{l}\text { Urban park or } \\
\text { other } \\
\text { public/urban } \\
\text { greenspace (3) }\end{array}$ & & & & & \\
\hline $\begin{array}{l}\text { Woodland/Forest } \\
\text { (4) }\end{array}$ & & & & & \\
\hline $\begin{array}{l}\text { Agricultural area } \\
\text { (e.g. meadow, } \\
\text { agricultural field) } \\
\text { (5) }\end{array}$ & & & & & \\
\hline Beach (6) & & & & & \\
\hline $\begin{array}{l}\text { Water bodies } \\
\text { (e.g. lake, river) } \\
\text { (7) }\end{array}$ & & & & & \\
\hline
\end{tabular}

If you have more than one dog, please answer the following questions regarding your largest dog.

For how long have you had your dog?

Do you walk your dog outside?

Yes (2)

No (7) 
For each place listed, please indicate the extent to which you visited it with your dog in the past month.

\begin{tabular}{|l|l|l|l|l|l|}
\hline & \multicolumn{5}{|c|}{ Frequency of visits } \\
\hline & $\begin{array}{l}\text { 0 - Did not } \\
\text { visit last } \\
\text { month (1) }\end{array}$ & $\begin{array}{l}\text { 1 - Less than } \\
\text { once a week } \\
\text { (2) }\end{array}$ & $\begin{array}{l}\text { 2 - Once a } \\
\text { week (3) }\end{array}$ & $\begin{array}{l}\text { 3 - Several } \\
\text { times a week } \\
\text { (4) }\end{array}$ & $\begin{array}{l}\text { 4 - Everyday } \\
\text { (5) }\end{array}$ \\
\hline Road/Street (1) & & & & & \\
\hline $\begin{array}{l}\text { Private garden } \\
\text { (2) }\end{array}$ & & & & & \\
\hline $\begin{array}{l}\text { Urban park or } \\
\text { other } \\
\text { public/urban } \\
\text { greenspace (3) }\end{array}$ & & & & & \\
\hline $\begin{array}{l}\text { Woodland/Forest } \\
\text { (4) }\end{array}$ & & & & & \\
\hline $\begin{array}{l}\text { Agricultural area } \\
\text { (e.g. meadow, } \\
\text { agricultural field) } \\
\text { (5) }\end{array}$ & & & & & \\
\hline Beach (6) & & & & & \\
\hline $\begin{array}{l}\text { Water bodies } \\
\text { (e.g. lake, river) } \\
\text { (7) }\end{array}$ & & & & & \\
\hline
\end{tabular}


Have you ever owned or lived with a dog before (including during childhood)? If yes, for how long?

Yes (1)

No (2)

Have you ever owned or lived with a cat before (including during childhood)? If yes, for how long?

Yes (1)

No (2)

Can you please select each of the species you know?

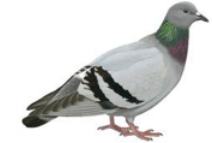

$\square 1$

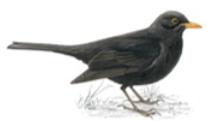

$\square 3$

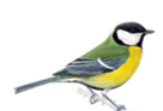

$\square 2$

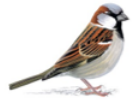

$\square 4$

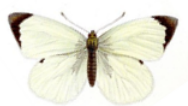

$\square 5$

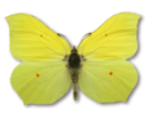

$\square 7$

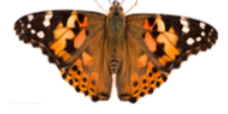

$\square 6$

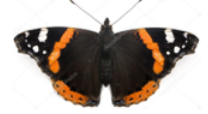

$\square 8$

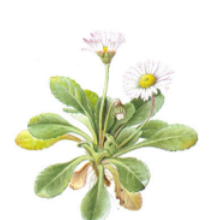

$\square 9$

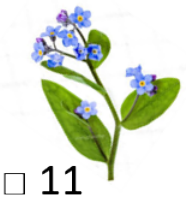

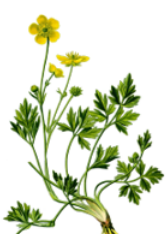

10

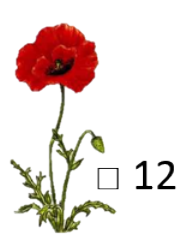

1 (1)

2 (2)

3 (3)

4 (4)

5 (5)

$6(6)$

7 (7) 
8 (8)

9 (9)

$10(10)$

$11(11)$

$12(12)$

Can you please name the species you know, from the above question's pictures (common name)?

$1(1)$

$2(2)$

$3(3)$

$4(4)$

$5(5)$

6 (6)

7 (7)

8 (8)

9 (9)

$10(10)$

11 (11)

12 (12) 
To what extent do you agree with each of the following statements?

\begin{tabular}{l|cccc}
$\begin{array}{c}1 \text {-Strongly } \\
\text { disagree (1) }\end{array}$ & $\begin{array}{c}2- \\
\text { Disagree } \\
\text { (2) }\end{array}$ & $\begin{array}{c}3 \text { - Neither } \\
\text { agree or } \\
\text { disagree (3) }\end{array}$ & $\begin{array}{c}4 \text { - Agree } \\
\text { (4) }\end{array}$ & $\begin{array}{c}5 \text { - } \\
\text { agree } \\
\text { (5) }\end{array}$ \\
$\begin{array}{c}\text { The so-called "ecological crisis" facing } \\
\text { humankind has been greatly } \\
\text { exaggerated (1) }\end{array}$ \\
$\begin{array}{c}\text { The earth is like a spaceship with } \\
\text { limited room and resources (2) }\end{array}$ \\
$\begin{array}{c}\text { If things continue on their present } \\
\text { course, we will soon experience a } \\
\text { major ecological catastrophe (3) }\end{array}$ \\
$\begin{array}{c}\text { The balance of nature is strong enough } \\
\text { to cope with impacts of modern } \\
\text { industrial nations (4) }\end{array}$ \\
$\begin{array}{c}\text { Humans are severely abusing the } \\
\text { environment (5) }\end{array}$
\end{tabular}

To what extent do you think dogs endanger wild species?

\author{
Not at all (1) \\ Not really (2) \\ Neither yes or not (3) \\ To some extent (4) \\ Very much (5)
}

To what extent do you think cats endanger wild species?
Not at all (1)
Not really (2)
Neither yes or not (3)
To some extent (4)
Very much (5) 
In which place did you spend most of your childhood?

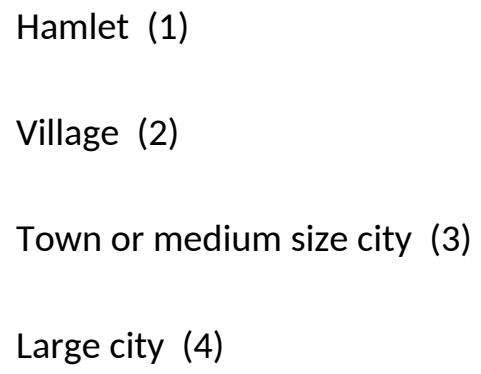

In which place do you currently live?

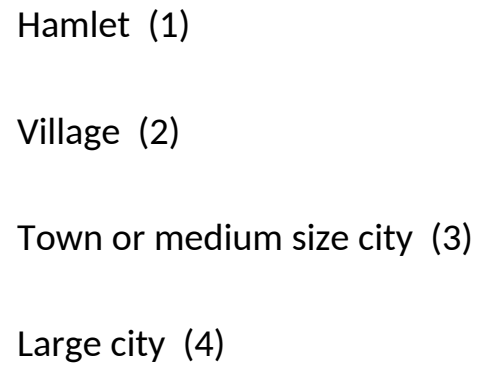

What is your highest level of education?

\author{
Below High School (1) \\ High School (2) \\ Professional diploma (3) \\ First degree (e.g. undergraduate) (4) \\ Second degree (e.g. Masters) (5) \\ Third degree (e.g. PhD) (6)
}

\title{
Thank you
}




\section{Survey B2: Dog shelter questionnaire - Before version}

\section{Informed Consent Form}

Dear Participant,

You are invited to take part in a survey on pet adoptions. You will be asked a few questions for the present survey, and contacted two months later by the researcher for a very short follow up survey.

Your responses will be anonymous. We will only ask you to provide an email address so we can contact you in two months. This information will be stored in a secured file only accessible by the researchers, and will be deleted after completion of the second part of the survey. There is no risk in taking part in this survey and there are no good or bad answers; we are simply interested in your opinion on the following matters regarding pet adoption. The information gathered will only be used for research purposes.

The questionnaire will take you about 5 minutes to complete. In exchange for participation, we will offer you a small gift.

Taking part in this study is completely voluntary. If you decide to take part, you are free to withdraw at any time.

Should you have any further questions about this project or if you have a problem of any kind, you may contact the principle investigator [blinded for review].

By choosing to participate, you are confirming that you are 18 years of age or older, that you have read and understand the information provided above and that you willingly choose to participate in this survey. If you choose to participate, please tick I ACCEPT, and sign.

\section{$\square$ I ACCEPT}

Signature

Thank you 
1) For each place listed below, please indicate the extent to which you visited it for leisure, in the past month ( 0 for 'Did not visit last month', 1 for 'Less than once a week', 2 for 'Once a week', 3 for 'Several times a week', and 4 for 'Everyday').

\begin{tabular}{|c|c|}
\hline Road/Street & $0-1-2-3-4$ \\
\hline Private garden & $0-1-2-3-4$ \\
\hline $\begin{array}{l}\text { Urban park or other } \\
\text { public/urban greenspace }\end{array}$ & $0-1-2-3-4$ \\
\hline Woodland/Forest & $0-1-2-3-4$ \\
\hline $\begin{array}{l}\text { Agricultural area (e.g. meadow, } \\
\text { agricultural field) }\end{array}$ & $0-1-2-3-4$ \\
\hline Beach & $0-1-2-3-4$ \\
\hline Water bodies (e.g. lake, river) & $0-1-2-3-4$ \\
\hline 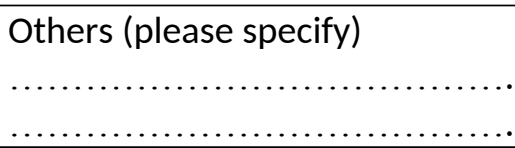 & $\begin{array}{l}0-1-2-3-4 \\
0-1-2-3-4\end{array}$ \\
\hline
\end{tabular}

2) For each of the following, please rate the extent to which you agree with each statement, using the scale from 1 to 5 ( 1 for 'Strongly disagree', 2 for 'Disagree', 3 for 'Neither Agree or disagree', 4 for 'Agree' and 5 for 'Strongly agree'). Please respond as you really feel, rather than how you think "most people" feel.

\begin{tabular}{|l|l|}
\hline My ideal vacation spot would be a remote, wilderness area & $1-2-3-4-5$ \\
\hline I always think about how my actions affect the environment & $1-2-3-4-5$ \\
\hline My connection to nature and the environment is a part of my spirituality & $1-2-3-4-5$ \\
\hline I take notice of wildlife wherever I am & $1-2-3-4-5$ \\
\hline My relationship to nature is an important part of who I am & $1-2-3-4-5$ \\
\hline I feel very connected to all living things and the earth & $1-2-3-4-5$ \\
\hline
\end{tabular}

3) In addition to the dog you are adopting, in your household, do you have....

$\square$ A dog-How many?

$\square$ A cat - How many?

$\square \mathrm{A}$ dog and a cat

$\square$ Another pet

$\square$ No pet

4) Have you ever owned or lived with a dog before (including during childhood)? $\square$ Yes $\square$ No If yes, for how long?

5) Have you ever owned or lived with a cat before (including during childhood)? $\square$ Yes $\square$ No If yes, for how long? 
6) In which place did you spend most of your childhood?

$\square$ Hamlet $\square$ Village $\square$ Town or medium size city $\square$ Large city

7) In which place do you currently live?

$\square$ Hamlet $\square$ Village $\square$ Town or medium size city $\square$ Large city

8) What is your year of birth?

9) Are you a $\square$ man / $\square$ woman?

10) What is your highest level of education?

$\square$ Below High School $\square$ High School $\square$ Professional diploma $\square$ First degree (e.g. undergraduate)

$\square$ Second degree (e.g. Masters) $\square$ Third degree (e.g. PhD)

11) To complete this research, we will need to contact you in two months for answering a similar questionnaire. Can you please provide us with an email address?

\section{Thank you}




\section{Survey B3: Online questionnaire for dog shelter respondents - After adoption}

Dear Participant,

You have participated in a survey on pet adoptions about two months ago when you adopted a dog at the shelter. We are grateful for this. As mentioned at the first stage, we would now like to invite you to complete a short follow-up survey.

The questionnaire will take about 5 minutes to complete, and would considerably help us to successfully conduct our research project.

Your responses will be anonymous. Data will be stored in a secured file. There is no risk in taking part in this survey and there are no good or bad answers; we are simply interested in your opinion regarding pet adoptions. The information gathered will only be used for research purposes.

Should you have any further questions about this project or if you have a problem of any kind, you may contact the principle investigator [blinded for review].

By choosing to participate, you are confirming that you are 18 years of age or older, that you have read and understand the information provided above and that you willingly choose to participate in this survey. If you choose to participate, please tick I ACCEPT.

Thank you

I accept (1)

I do not accept (2)

Please report the ID number that was attributed to you for this survey (in the email you received). 
For each place listed below, please indicate the extent to which you visited it for leisure, in the past month.

\begin{tabular}{|l|l|l|l|l|l|}
\hline & \multicolumn{5}{|c|}{ Frequency of visits } \\
\hline & $\begin{array}{l}\text { 0 - Did not } \\
\text { visit last } \\
\text { month (1) }\end{array}$ & $\begin{array}{l}\text { 1 - Less than } \\
\text { once a week } \\
\text { (2) }\end{array}$ & $\begin{array}{l}\text { 2 - Once a } \\
\text { week (3) }\end{array}$ & $\begin{array}{l}\text { 3 - Several } \\
\text { times a week } \\
\text { (4) }\end{array}$ & $\begin{array}{l}\text { 4 - Everyday } \\
\text { (5) }\end{array}$ \\
\hline Road/Street (1) & & & & & \\
\hline $\begin{array}{l}\text { Private garden } \\
\text { (2) }\end{array}$ & & & & & \\
\hline $\begin{array}{l}\text { Urban park or } \\
\text { other } \\
\text { public/urban } \\
\text { greenspace (3) }\end{array}$ & & & & & \\
\hline $\begin{array}{l}\text { Woodland/Forest } \\
\text { (4) }\end{array}$ & & & & & \\
\hline $\begin{array}{l}\text { Agricultural area } \\
\text { (e.g. meadow, } \\
\text { agricultural field) } \\
\text { (5) }\end{array}$ & & & & & \\
\hline Beach (6) & & & & & \\
\hline $\begin{array}{l}\text { Water bodies } \\
\text { (e.g. lake, river) } \\
\text { (7) }\end{array}$ & & & & & \\
\hline
\end{tabular}


For each of the following, please rate the extent to which you agree with each statement. Please respond as you really feel, rather than how you think "most people" feel.

\begin{tabular}{|c|c|c|c|c|c|}
\hline & $\begin{array}{l}1 \text { - Strongly } \\
\text { disagree (1) }\end{array}$ & $\begin{array}{c}2- \\
\text { Disagree } \\
\text { (2) }\end{array}$ & $\begin{array}{c}3 \text { - Neither } \\
\text { Agree or } \\
\text { Disagree } \\
\text { (3) }\end{array}$ & $\begin{array}{l}4 \text { - Agree } \\
\text { (4) }\end{array}$ & $\begin{array}{c}5- \\
\text { Strongly } \\
\text { agree } \\
(5)\end{array}$ \\
\hline $\begin{array}{l}\text { My ideal vacation spot would be a } \\
\text { remote, wilderness area (1) }\end{array}$ & $C$ & & & & \\
\hline $\begin{array}{l}\text { I always think about how my actions } \\
\text { affect the environment (2) }\end{array}$ & $\checkmark$ & & & & \\
\hline $\begin{array}{c}\text { My connection to nature and the } \\
\text { environment is a part of my } \\
\text { spirituality (3) }\end{array}$ & & & & & \\
\hline $\begin{array}{l}\text { I take notice of wildlife wherever I am } \\
\text { (4) }\end{array}$ & ) & 0 & & & \\
\hline $\begin{array}{l}\text { My relationship to nature is an } \\
\text { important part of who I am (5) }\end{array}$ & ) & ) & & & \\
\hline $\begin{array}{l}\text { I feel very connected to all living } \\
\text { things and the earth (6) }\end{array}$ & & & & & \\
\hline
\end{tabular}

Q13 If you have more than one dog, please answer the following questions regarding the dog you recently adopted at the dog shelter.

When did you adopt your dog at the shelter? (Please give an approximate date)

Do you walk your dog outside?

Yes (2)

No (7)

\section{Thank you}

